Article

\title{
Sustainable Tourism: A Hidden Theory of the Cinematic Image? A Theoretical and Visual Analysis of the Way of St. James
}

\author{
Lucrezia Lopez ${ }^{1, *(1)}$, Enrico Nicosia ${ }^{2}$ and Rubén Camilo Lois González ${ }^{1}(\mathbb{D}$ \\ 1 Department of Geography, University of Santiago de Compostela, Praza da Universidade 1, \\ 15782 Santiago de Compostela, Spain; rubencamilo.lois@usc.es \\ 2 Department of Education, Cultural Heritage and Tourism, University of Macerata, P.le Bertelli 1, \\ 62100 Macerata, Italy; enrico.nicosia@unimc.it \\ * Correspondence: lucrezia.lopez@usc.es
}

Received: 28 August 2018; Accepted: 1 October 2018; Published: 11 October 2018

check for updates

\begin{abstract}
The attractiveness of a tourist destination is derived from multiple material and immaterial elements. Cinema is both a tourist communication channel and provides a target market for a destination. Many regions offer a great variety of potential locations desirable for their scenic beauty and artistic and monumental heritage. The main aim of this paper is to analyze the concept of sustainable tourism as a pillar of the contemporary cinematic discourse on pilgrimage routes, combining theoretical and empirical methodologies. It begins by analyzing how, given their power, images are narrative instruments that assume a true performative value of geographical reality. The research then focuses on the cinematographic space and visual cinematographic discourse. The case study is sustainable tourism along the Way of St. James (Spain). The material is a corpus of two documentary films. Their moviescapes highlight the presence of a sustainable filmic theorem within a potential cinematic genre-pilgrimage movies. Thus, this study contributes to the investigation of how sustainable pilgrimage tourism practices are used in cinematic production as a possible movie theorem. It presents a conclusive critical evaluation of the role and message of these moviescapes.
\end{abstract}

Keywords: pilgrimage and religion tourism; sustainable pilgrimage tourism; moviescapes; the Way of St. James

\section{Introduction}

The impact of visual media on the public is undeniable. Film and television productions place the spotlight on stories, artists, places, lifestyles, customs, and practices, both real and active. In doing so, they are able to seduce millions of spectators. This seduction can then engender the acquisition and the consumption of goods associated with a much-loved production: think about the phenomenon of the products associated with blockbusting series, such as the toys and clothing of Star Wars and The Lord of the Rings. Film and television productions are also tools for promoting natural and cultural environments. The viewer is able to reject these elements or, on the contrary, dream about them and eventually endorse them [1].

The intention of the present paper is to examine beyond some of these introductory and consolidated issues in order to propose new research approaches that create a dialogue between tourism sustainability and the film industry. This work is situated within the realm of tourism studies that have placed their academic and scientific interest on the Way of St. James. The Way of St. James is a medieval pilgrimage route and was declared the First European Cultural Route in 1987. Subsequently, the French Way was declared a World Heritage Site by UNESCO (United Nations Educational, Scientific and Cultural Organization) in 1993. These recognitions have assigned the pilgrimage the role of a star 
tourist product in the Autonomous Community of Galicia, an achievement that was reached due to the construction and restoration of hospitality facilities for pilgrims [2,3]. Today, the French Way is a reference for pilgrimage tourism; its inclusiveness of pilgrims with different profiles has transformed it into a popular destination that can have negative impacts for the territory. However, the pilgrim, unlike the tourist, acts more respectfully and sustainably toward the environment, and this is what will be visualized through the primary sources analyzed.

From a historical perspective, pilgrimage tourism has shared traits with sustainable tourism. Both are respectful of the natural, urban, and monumental environment, and interpret the tourism tendencies of the 21st century as well as the behavioral guidelines of the mobile person. According to Saarinen [4], the idea of sustainable tourism includes the concepts of responsible tourism formulated by Goodwin [5], as both refer "to tourism development principles and practices aiming to make places better for people to live and visit". Both forms of tourism "intend to minimize the negative and maximize the positive social, economic, and environmental impacts of tourism in destination communities and environments, by promoting ethical consumption and production among all stakeholders" [4] (p. 2).

The present study is inspired by the new approach demanding reflection on the relationship between pilgrimage and religious tourism in sustainable terms. This relationship can be expressed in various ways; this study turns its attention of one of the most commonly used visual media (the cinema) as a tool of communication and sensitivity toward these behavioral precepts. The filmic language has always been able to narrate the permanence of time and history. These attributes emerge in a pilgrimage route that wants to provide a sustainable model, even after more than 12 centuries of existence [6]. Heritage and recreated landscapes are sustainable, too. The return to slow movement, calm conversations with other pilgrims, and itineraries understood as a walk evoke the refusal to grow and condemn the useless consumption of energy. In other words, this model minimizes the ecological footprint. Finally, anything the pilgrim consumes (whether true or false) is considered local, natural and healthy. The gastronomy of the Way of St. James is seen as the result of an ancestral culture, derived from peasants, and associated somehow with the myth of traditional agrarian sustainability.

Until now, cinematic research and pilgrimage tourism has been neglected. For instance, few studies have explored the relationship between the Way of St. James and cinema. Previous studies, such as those by Lopez et al. [7], Rodríguez Campo and Fraiz Brea [8], Escudero Gómez [9] and Smith [10] have addressed this relationship by considering cinema as a touristic resource that is able to project a local image onto an international scale. They considered cinematographic production a space of (re)production of historical and local identity. This general research line contributes to media and marketing studies as it highlights the increasing promotional function of cinema. Because of this, the present article departs from a reflection on functions of the moving image, to demonstrate our working hypothesis: the presence of a filmic theorem relating to sustainability along the Way of St. James. This is translated and projected through the many documentaries available online. We consider that the paradigm of sustainability inspires and directs cinematographic productions and determines the behavior of tourists, who in some cases are the spectators themselves. Another factor that differs with respect to previous studies is the sources. Amongst the different cinematic genres, we choose to qualitatively analyze two documentaries, as they represent the closest proximity to reality. If road movies are thematically dominated by movement [11], pilgrimage movies can become a filmic genre promoting sustainable tourism. By means of cinematographic creative tools, movie pilgrimage movement is characterized by sustainable features (slow mobility, local economic activities, and contact with local community) that the selected moviescapes highlight. Thus, this study contributes to the understanding about how sustainable pilgrimage tourism features are used in the cinematic production as a possible movie theorem.

This article is divided into four sections. The first provides a literature review divided into two sections. In it, we analyze the characteristics and advantages of considering film as a cultural product and medium for territorial studies $[12,13]$. For this reason, the main concern of film analysis is to prove the authenticity of the representation of the place in which the film is set. Despite the fact that the 
content of the film industry is now the subject of interdisciplinary studies, this analysis focuses on the tourism industry, which in recent years has turned its attention on the influence of the moving image when undertaking a journey [14-16]. In the second part, we justify the reasons why film provides useful data for geographical interpretation and becomes an important document for information for the discipline [17]. In this section, we explain the qualitative methodology used. In the results and discussion sections, we support an interpretive and comparative interpretation of the filmic theorem according to moviescapes and a literature review on the Way of St. James. In the conclusion, we review the contributions of cinematographic production to the promotion of sustainable tourism and highlight the need for studying documentaries and filmic images.

\section{Literature Review}

\subsection{Moviescapes}

Seeing and travelling are evocative and inseparable elements for any film lover, demonstrated by the transformation that often occurs from the voyeur into the voyageur. The English language renders the movement between the gaze and the place, sight and site, a fluid whole that allows us to perceive the importance of the spectator who becomes the voyageur and a tourist of the places that have been emotionally moving and made an impression. According to Escher, a cinematic landscape or landscape in movies may be interpreted as the representation of material, real-world, and subjectively organized scenery on the earth's surface, which is loaded with cultural additions, or a fictitious environment in the day-to-day dimension. Similar to the themes and subjects used in painting, literature, photography, and even movies, this works because there is no landscape that has been seen for the first time [18] (p. 309) (cf. [19]).

The audience perceives a landscape it has seen before, and thus it is a purposefully created product, so they process this as a substitute in its own subjective sense of perception. It is not a question of whether the landscape presented actually reflects how the audience sees the physical world, but rather of whether the recipient trusts the representation and the manner in which certain landscape elements are selectively perceived. These imaginary landscapes contribute to the success of the movie through various positions and mechanisms of action. The varied representation and narrative function of landscape in movies is thus visualized in the area of tension between setting and emotion $[20,21]$.

The landscape can be verbally, visually, and graphically described, but it can also be narrated. In that case, they are relational spaces in which the places, subjects, and events do not exist in a void but are intersected in social time and space, collaborating in the construction of an image. The landscape is one of the elements that lead the filmmaker to select a place in which to set their narratives. To experience the landscape and, in particular, an urban landscape, is thus equivalent to its cinematographic representation. In Paris, Capital of the Nineteenth Century, Walter Benjamin [22] invents the contemporary urban landscape as a place explored by the flâneur, a place that is traversable but elusive, a mirror of the social phenomena of the time. Also, from its inception with panoramic films, cinema has been a genre of media composed of scenographic sights that transform the journey from one place to another, then into a diffuse practice. The dawn of cinema invented the panoramic view, which included site-seeing journeys and the spatial-visual desire to circulate and move, which characterized the new modern times. Filmic representation was no longer static, as it is not only the protagonists that move in the landscape; rather, it is the representation technique itself that inspires movement (see, for example, a film such as Panorama from Times Building, New York of 1905). As for site-seeing, film creates its own architectural landscape that engages the gaze in its relationship to movement. When film produces travel stories, it creates a space for seeing and scrutinizing. Behaving as a traveler, the itinerant spectator reads the panoramas in movement as exercises of imagination. Between geography and visual narration, it is possible to grasp two-dimensional relationships based on the conviction that spatial analysis can obtain assistance from indirect sources, capable of offering a new dimension of 
reality to geographic knowledge, based on lived and interpretable space [23-26]. It is an analysis of those individual geographies that shape human territoriality. According to Butler [27], people often choose their tourist destination depending on what they have seen via popular audiovisual means, like television and cinema. The influence of these images can be voluntary, involuntary, accidental, conscious, or unconscious. He also suggests that because people now read less frequently, anything appearing in films and television penetrates society more easily.

Specific weight is given to the role of autonomous factors like "the news" and "popular culture". In contrast to elitist or fringe culture, which influences a small percentage of the population, popular culture strengthens and reflects models of communication and consumption for the wider general public. Films are an important fragment of popular culture. They can transmit essential information about a destination in a short time and to many people. Regarding the role of popular culture in shaping a "destination image" within the framework of tourism, Urry (2002) claims that one of the basic motivations for tourists to visit a location is the expectation that these people may have different experiences to those they would have in their home location [23].

Today, however, it is territories that "exploit" cinema, using it as an instrument for promoting tourism (Figure 1). It is not easy to answer the question of why films and fictions induce tourism, by transforming a location into a tourist destination. For a long time, it was thought that it was because in some films or fiction you can see images that entice the viewer to go and visit the locations admired during the viewing. In reality, the phenomenon is more complex and also has to do with the themes of the film, the sequences and the relationships between the characters: in short, it is the magic of the film as a whole that makes the set palatable. But this happens when the film in all its elements works because it is a "soft sale" of the territory, able to appeal not only to rational elements, but also and above all to emotional ones [24,25,28,29].

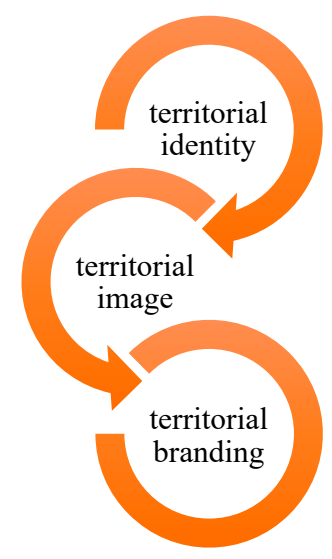

Figure 1. The role of cinema in the construction of the tourist space. Own elaboration.

\subsection{Film-Induced Tourism}

Pioneering studies on the subject of film-induced tourism have been completed by Cohen [26] and Butler [27], and later by Riley et al. [14]. Investigations in the field have proceeded slowly, with Beeton, a scholar at the University of La Trobe (Melbourne, Australia), providing significant contribution with her work Film-Induced Tourism [25]. Notably, both Butler [27] and Beeton [28] revealed traces of the origins of the phenomenon in travel diaries and postcards from the time of the Grand Tour, and the descriptions, images, and photographs of places made popular by novelists during the Romantic period. Travel and cinema, like travel and literature, are activities that allow people to escape from their daily routine, allowing them to delve into new realities and contexts and thus broaden their knowledge and horizons.

Tooke and Baker [15] raised the concern that the film location will not often have the carrying capacity to cope with large increases in visitors. This could result in a number of potential undesirable consequences, such as increased vehicle traffic, pedestrian congestion, and loss of privacy and local 
facilities for locals. The destruction of the natural environment is also a concern. For example, filming of The Beach and the subsequent film tourism resulted in extensive environmental damage to Phi Phi Lae Island in Southern Thailand. Another problem that occurs is when the location appears different to how it is portrayed in the film, resulting in a decrease in visitor satisfaction [30]. Whereas Karpovich [31] is one of several researchers to state that film tourism, teletourism, and movie tourism are the same concept, Torchin [32] distinguished between movie- and television-induced tourism, asserting that television has a longer, more levelled impact on featured localities because it has lasting appeal, drawing visitors for many years [33]. Previous studies have shown that television programs actively increase visitor numbers to certain destinations [16,34-40] or cause increased interest in these places [41]. Quite possibly, viewing localities through visual media is even a destination experience itself, offering the opportunity to gather additional information $[14,40]$.

In terms of the importance of this sector of tourism, research by $\mathrm{O}^{\prime} \mathrm{Connor}$ et al. [37] suggested that a fifth of inbound U.K. tourists visit to explore film locations. This figure is expected to grow over the coming years due to the increasing amounts of time people are dedicating to watching television, greater interest in film, and continuous technological developments [42-46]. Tooke and Baker [15] studied four television dramas and documented their subsequent effects upon numbers of visitors to featured locations. In each case, visitor numbers increased dramatically. There are many different forms of film-induced tourism and Table 1 provides a comprehensive overview, along with their common characteristics and various examples in relation to published academic literature:

Table 1. Forms and characteristics of film-induced tourism $[25,34,35,43-46]$.

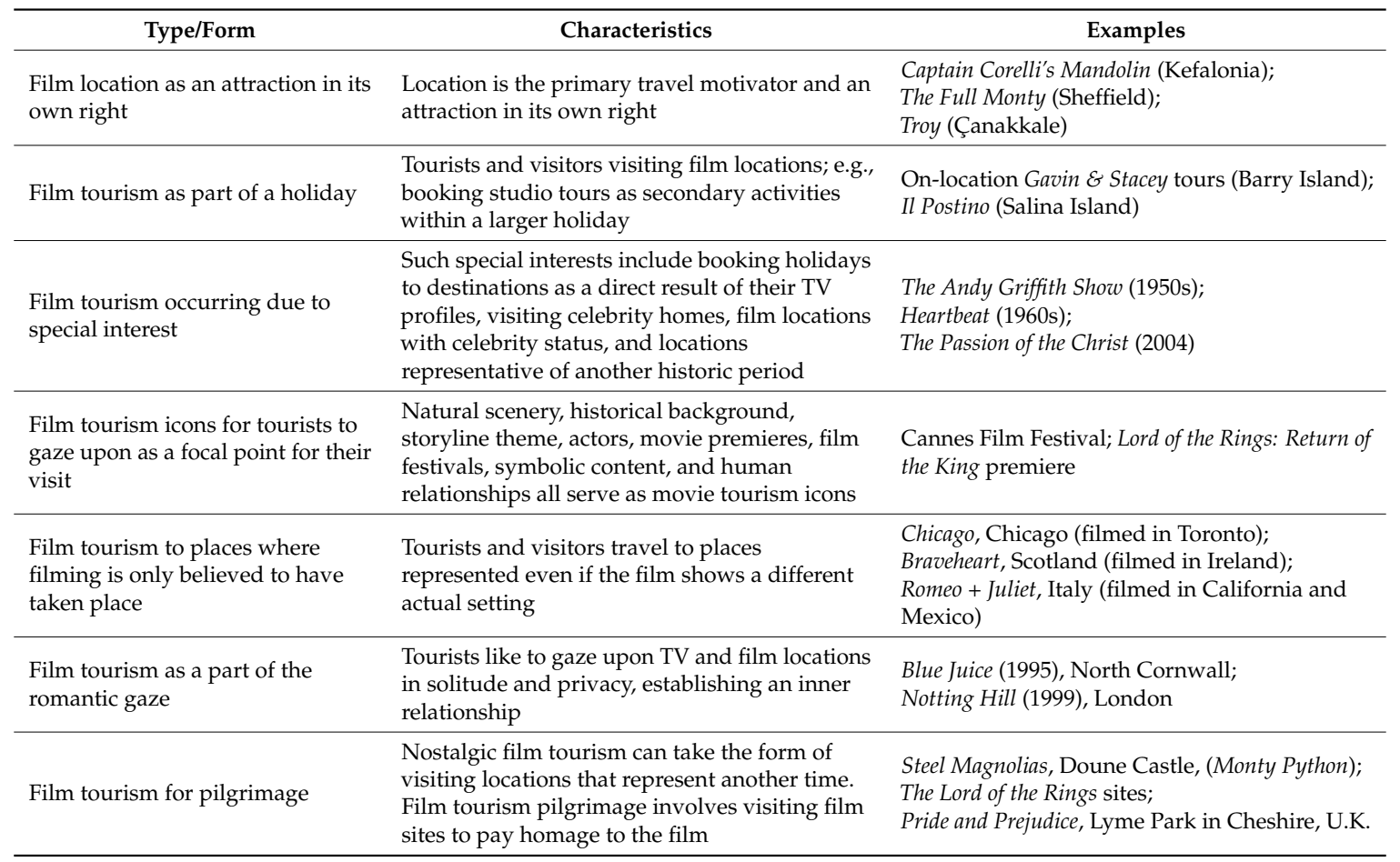

Film-induced tourism is defined by the Scottish Tourism Board as, "the business of attracting visitors through the portrayal of a place or a place's storylines in film, video, and television" [47]. Beeton, like Buchman et al. [48] (p. 233), defined it as, "visits to sites where movies and TV programs are filmed as well as to tour production studios, including movie-related theme parks [ ... ] what is of interest is the tourist activity associated with the film industry" [25] (p. 9). Hudson and Ritchie [49] suggested that film tourism is the tourism that is generated as a result of the appearance of a destination or attraction in film, video, or television. In their analysis of this phenomenon, they identified four general fields of analysis: the estimation of the distinct influence of the film on travel decisions, the 
formation of specific categories of film tourists, the measurement of the effects of films on the number of incoming tourists and on the lives of residents, and the analysis of destination marketing activities connected to film tourism.

Another term used particularly in the British media is set-jetters [50] - tourists who choose to travel to a specific place with the purpose of visiting the surroundings, the areas, and the locations used for one or more films. It is therefore a segment of tourism demand particularly characterized and determined by the influence of an image on the small and big screens, a market that benefits from travelling to places where film stars have performed or stayed, and is influenced by what Anglo-Saxons define as celebrity culture [51].

\section{Materials and Methods}

Particularly due to the power of the images it is capable of producing and emotions it evokes, film can assume a true performative value in relation to its geographic reality $[29,43]$. This is because, once internalized by the local community, it is reproduced in individual and collective behaviors, providing identity references that guide and characterize the process of territorialization. Setting, location and decor represent some of the essential components in the production of a film, a story, a TV series or a documentary. A film or series feed off the genius of the directors and the charm of the actors, but also from the real or reproduced locations in which the films are shot; in fact, for many television and film productions, the sets themselves become protagonists [46]. Shooting across different regions, creating and projecting content with territorial identity value can be strategies of patrimonial tutelage [52]. The cinematographic space possesses a spatial system that can be compared to a representational space [53] because it employs the physical space and its objects, it is experienced and represented through images and symbols and is a space that the industry appropriates for its own purposes. The language of film encompasses all narrative modalities: verbal, non-verbal, audio and visual [54]. The expression "cinematic discourse" encompasses all modalities of cinematographic representation, meaning and communication [55] and is based on two planes: diegetic (history of the film, narratives and actors) and extra-diegetic (the film as an artistic product of professionals) [54,56].

We opted to characterise cinematographic space through visual cinematographic discourse of the diegetic plane. In 2001, Rose [57] published the volume Visual Methodologies, which manifested the growing contemporary importance of the visual dimension for the cultural construction of Western social life. In this tribute to visive methodologies, she highlighted the importance of images in transmitting knowledge, power, and culture. Stafford [58] defended the construction of knowledge of the world based on images rather than written text. Thus, the act of seeing has been transformed into an act of knowing [59], especially in Western cultures. As far as cinema studies are concerned, in "Everyday experience in Israeli cinema: The port and the city's margin", Peri-Bader [60] proposes a qualitative interpretation of cinematic production in order to confirm his working hypothesis. His cinematographic analysis is based on the reconstruction of urban spaces departing from the projected images. Drawing on this precedent, we propose a qualitative study of cinematic production relating to the Way of St. James, with two documentaries as our sources. For our qualitative research, we also draw upon statistical data relating to pilgrimage from the Pilgrim's Reception Office and the Way of St. James Observatory. In this latter case, only the series up to 2010 is available, as the entity ceased to exist for economic and political reasons. Furthermore, we support our working hypothesis and our interpretation of the moviescapes using Way of St. James literature.

Firstly, to explain the methodology adopted, we consider that each image follows its project, responding to a figurative work in which the production is both a theoretical proposition and a formal demonstration [61,62]. Didi-Huberman [63] introduced the idea of theory in images in relation to the iconographical program., Images are also conceptual and perceptive: they are vehicles for storing, manipulating, and communicating the information that allows one to be in contact with the physical and visual environment [64]. There is a variety of elements that compose a work and that can be treated differently, allowing different analyses $[65,66]$. Analysis of a film has an ontological nature in that it 
belongs to the order of knowledge and it moves on a double level: an empirical space determined by movements and a plane of ideas crossed by the theme [67]. Each cinematographic production has its primordial idea and a determined orientation that is reflected in its images [66]. The universe of the film is understood through the relationship between the changes in places and states of the film. The result is a visual experience with representational and sensory aspects that connect the documentary's pilgrims and their viewers.

Each visual analysis has its own methodology based on the objectives and message of the project [68], which depends on the critical understanding of the person advancing this visual reading. For this reason, to analyze the cinematographic visual language of the selected material, we mark some qualitative methodological guidelines. Our working hypothesis is the presence of the new filmic theorem of sustainability [33] in the Way of St. James documentaries. To examine this, the criteria of Deleuze are used: the need to reflect on the thinking of the film is shown, the formalities of representation are highlighted, and the theoretical figures of the documentaries are interpreted as significant elements [69]. For this reason, we assume the role of film analysts, deciding which documentaries and which images to select [65]. We set a scale of interpretative focuses that correspond to the message theorized in the documentaries. These images have a range of driving forces of filmic syntax; in using them, a certain coherence is produced in the decodified message. They are qualitative indexes used to read and interpret sustainability [68,70].

We think that these present particularities allow us to speak of an iconic recognition through which identification requires conceptual knowledge [64]. The figures selected are" theoretical figures" [63], that is, figures able to produce and interpret the thematic axis (Figure 2). We recognize the moviescapes that contain iconic signifiers [71], which, when representing specific sociocultural objects, become key factors of sustainable urban tourism. Likewise, it must be possible to recognize an equivalent of reality. As stated, the relationship with tourism sustainability is the selection criteria of these visual messages, which are presented below through a selection of cinematographic images. The framework used in sampling the images in the two documentaries included their level of representation of sustainable aspects that are detailed in the following paragraph. Images were selected according to the presence of theoretical iconic images. Through this process, the qualitative analysis of an audiovisual production is based on a semiotics of the images, through which a grammar and semiotics of the movement that organizes the meaning is achieved [70]. Through theoretical images, social dynamics and territorial phenomena are observed and interpreted and linked to urban tourism sustainability. Through this interpretive exercise, we highlight the potentialities of the visive language when investigating knowledge and theories hiding behind the camera. Their immediate value is an ally for the promotion and learning of customs and habits.

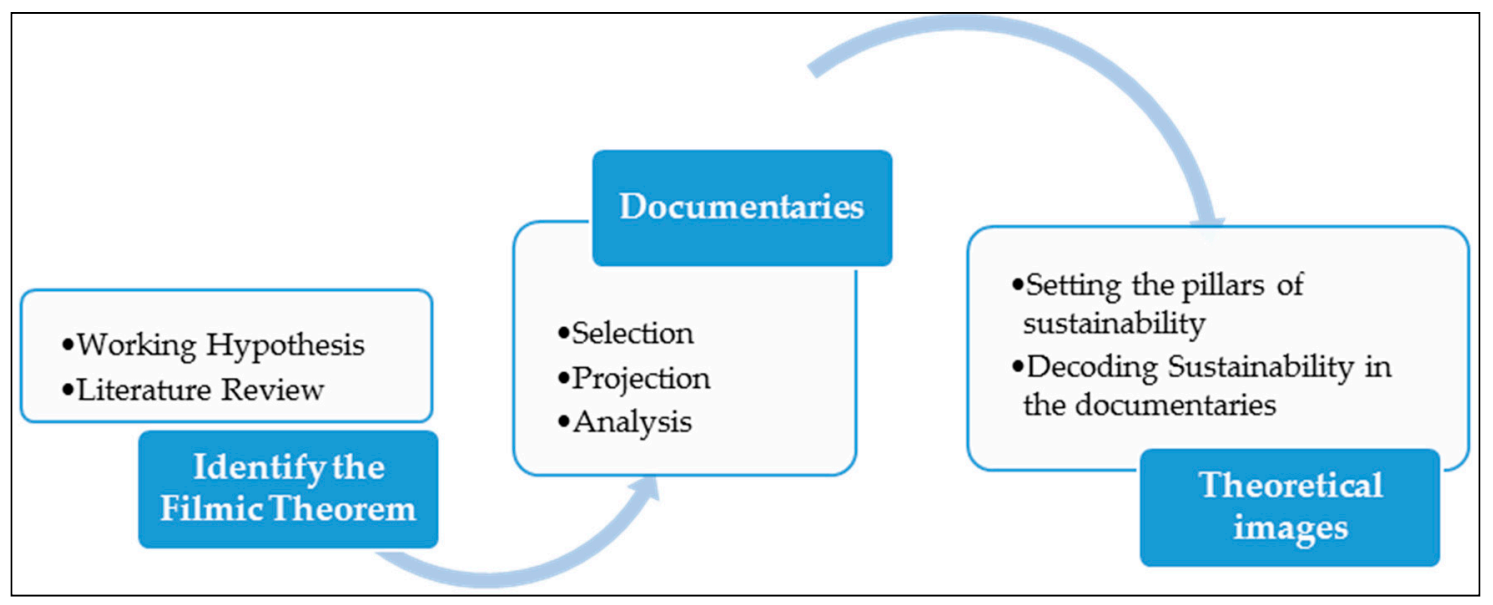

Figure 2. Methodological steps. Own elaboration drawn from [61-66,69,72]. 
The set of existing relationships between geography and film is based on the premise that spatial analysis can draw on indirect sources, offering geographic understanding a new vision of reality based on the experienced and interpretable space [73]. Documentaries are considered the origins of cinema and the first sequence in the history of French cinema is a documentary [74,75]. Each documentary is a unique work that presents a relationship with reality. Unlike a film, nothing needs to be invented or staged, as the information it transmits is based on reality. Those who participate in its production are closely linked to reality. They are not playing a role, and they are free in front of the camera [74]. The documentary character and accessibility of the sources are two aspects to consider if we are to measure the determination capacity of a film. A documentary implies a greater level of reality and the desire of the producer, which often coincides with the protagonist, to reproduce details and emotions to reach a level of empathy with its spectators. Accessibility is a great advantage as it contributes toward achieving the objective of democratizing the sources and information.

In Table 2, we present the documentaries referring to the Way of St. James that are available online.

Table 2. Online documentaries on the Way of St. James.

\begin{tabular}{|c|c|c|}
\hline Title & Duration & Year \\
\hline El Camino di Santiago no un camino de rosas & 00:09:59 & 2006 \\
\hline Camino de Santiago Documentary Film-The Way & $01: 15: 38$ & 2010 \\
\hline El Camino de Santiago & 00:44:00 & 2011 \\
\hline Walking the World-Cammino de Santiago $1^{\circ}$ week & $00: 51: 51$ & 2013 \\
\hline Walking the World-Cammino de Santiago $2^{\circ}$ week & $00: 51: 54$ & 2013 \\
\hline Walking the World-Cammino de Santiago $3^{\circ}$ week & 00:51:04 & 2013 \\
\hline Walking the World-Cammino de Santiago $4^{\circ}$ week & $00: 51: 10$ & 2013 \\
\hline Walking the World-Cammino de Santiago $5^{\circ}$ week & $00: 52: 21$ & 2013 \\
\hline Walking the World-Cammino de Santiago $6^{\circ}$ week & $00: 51: 26$ & 2013 \\
\hline Uma Jornada pelo Caminho de Santiago & 02:08:48 & 2014 \\
\hline Sei vie per Santiago & $01: 24: 20$ & 2015 \\
\hline Camino de Santiago 2015-La Via de la Plata & $00: 33: 58$ & 2015 \\
\hline Diario di viaggio & $00: 56: 03$ & 2015 \\
\hline In Cammino I Strada per Santiago 2016 & $00: 54: 22$ & 2016 \\
\hline Santiago-Anime in Cammino & $03: 13: 26$ & 2016 \\
\hline Il Cammino di Santiago-La via francese & $00: 50: 13$ & 2018 \\
\hline
\end{tabular}

Table 3 summarizes the two films analyzed, which are:

Camino de Santiago Pilgrimage-The Way Film is a documentary film produced by Mark Shea, who completes the French Way between April and May 2004 over 34 days. The documentary is the result of his pilgrimage, which he documents and shares with others. He is the presenter and acts as a guide and producer of the film. His documentary is a guide as it accompanies the journey with explanations and interviews.

Uma Jornada pelo Caminho de Santiago is a documentary film about the French Way that takes place over 35 days. The languages employed are music and visuals. It is a sequence of images representing the Way of St. James and the pilgrims. The music is the only sound in the film, and this places all the spectator's attention onto what is being seen. It is an excellent and carefully shot video about the Way, in which good, high-definition images stand out. The scenes are interesting, with movement in the light, and a full tour of the Way and places of interest in the cities along the pilgrimage. The Way is the real protagonist, with its natural landscape and heritage treasures. This technique allows the spectator to better reflect on what they are watching. Perhaps this combination of images and music reinforces the sense and desire for the journey. 
Table 3. Research sources [76,77].

\begin{tabular}{ccc}
\hline Title & $\begin{array}{c}\text { Camino de Santiago Pilgrimage } \\
\text { The Way Film }\end{array}$ & $\begin{array}{c}\text { Uma Jornada pelo Caminho } \\
\text { de Santiago }\end{array}$ \\
\hline Genre & Documentary & Documentary \\
Year & 2010 & 2014 \\
Country & Australia & Portugal \\
Duration & $01: 15: 38$ & $2: 08: 48$ \\
Starting Point & Saint-Jean Pied de Port & Saint-Jean Pied de Port \\
Protagonists & Mark Shea & Andre Luiz \\
Source & http://www.overlander.tv/the- & https://www.youtube.com/watch?v= \\
& way-camino-de-santiago-film/ & DLsPX2K9vv0movie=tt2406422 \\
\hline
\end{tabular}

After the collection of data about the online documentaries (Table 2), we selected two of them, as indicated in Table 3. The criteria for their selection are:

(1) Their producers come from two different countries: Portugal and Australia, a close and a distant country. This geographical distance might determine a different territorial perception and representation.

(2) The starting point of the two documentaries is Saint-Jean-Pied-de-Port. Thus, the representing territories would coincide throughout the projection. Documentaries were downloaded from the Internet and saved on a personal computer.

They were watched by using a media player reproducer, which allows stopping the projection and copying the current moviescape. We viewed the documentaries three times. The first time was meant to understand its main content and to confirm the coherence of the choice. During the second viewing, we proceeded to select those moviescapes that responded to our analytical framework aimed at showing the sustainable aspects of the pilgrimage tourism (mobility, accommodation, sociability, local heritage and gastronomy). In terms of the heritage and local offer, we propose some of their potential moviescapes that responded to well-known attractions along the Way of St. James, such as the Cathedrals of Burgos and Astorga, in order to point out the marketing power of cinematic images. In the case studies, the cinematographic narratives in movement generate a sense of meaning, as one of the pillars of analysis is precisely that the slow movement of pilgrimage gives way to significant practices that can be used to understand the features of tourism sustainability. Some of the theoretical figures are introduced in the following paragraph, through which dialectics between reality and production make the production's discourse explicit.

\section{Results and Discussion}

As was asserted in the introduction, our working hypothesis is to recognize and make explicit the filmic theorem of sustainability (slow mobility, pilgrims' healthy practices, and permanence of the Way), which inspires documentary productions about the Way of St. James pilgrimage. As a pioneer in terms of theoretical and thematic research into audiovisual sources about the Way, we link the results with other Way of St. James studies which, being related to more than only cinema, are situated within the context of territorial studies on pilgrimage. We highlight very general results, and others that are more specific. In general, both documentaries demonstrate an intention to highlight the value of the Way, especially the French Way, which, as is shown in Figure 3, is the most popular route amongst pilgrims and is the route that receive the most attention.

The valuation of the Way occurs on two levels: spatial and experiential. At the spatial level, the Way of St. James is the protagonist; it is the real space of the Way that coincides with the setting of the documentaries. This reinforces the sense of space and the capacity of the spectator to experience it as a visual experience. Let us look at the second aspect in which the visual experience of the Way is expressed through images in movement. It is a slow movement that facilitates the relationship and the recognition of theoretical figures, of filmic figures that we employ to decodify production. With regard 
to the specific results, we present them below through the visual support of moviescapes that highlight the function of pilgrimage in the promotion of sustainable tourism and, when possible, with statistical data from the Santiago de Compostela Pilgrim Office [78]. To this end, we assume that the distinctions between pilgrimage and tourism are not clearly defined, since a tourist can also be interested in visiting a church $[79,80]$ and this is because religious and pilgrimage tourism are considered a sub-group of cultural tourism [81,82]. Although initially pilgrimage presupposed an existential modality, nowadays, it shares some recreational and leisure aspects with tourism.

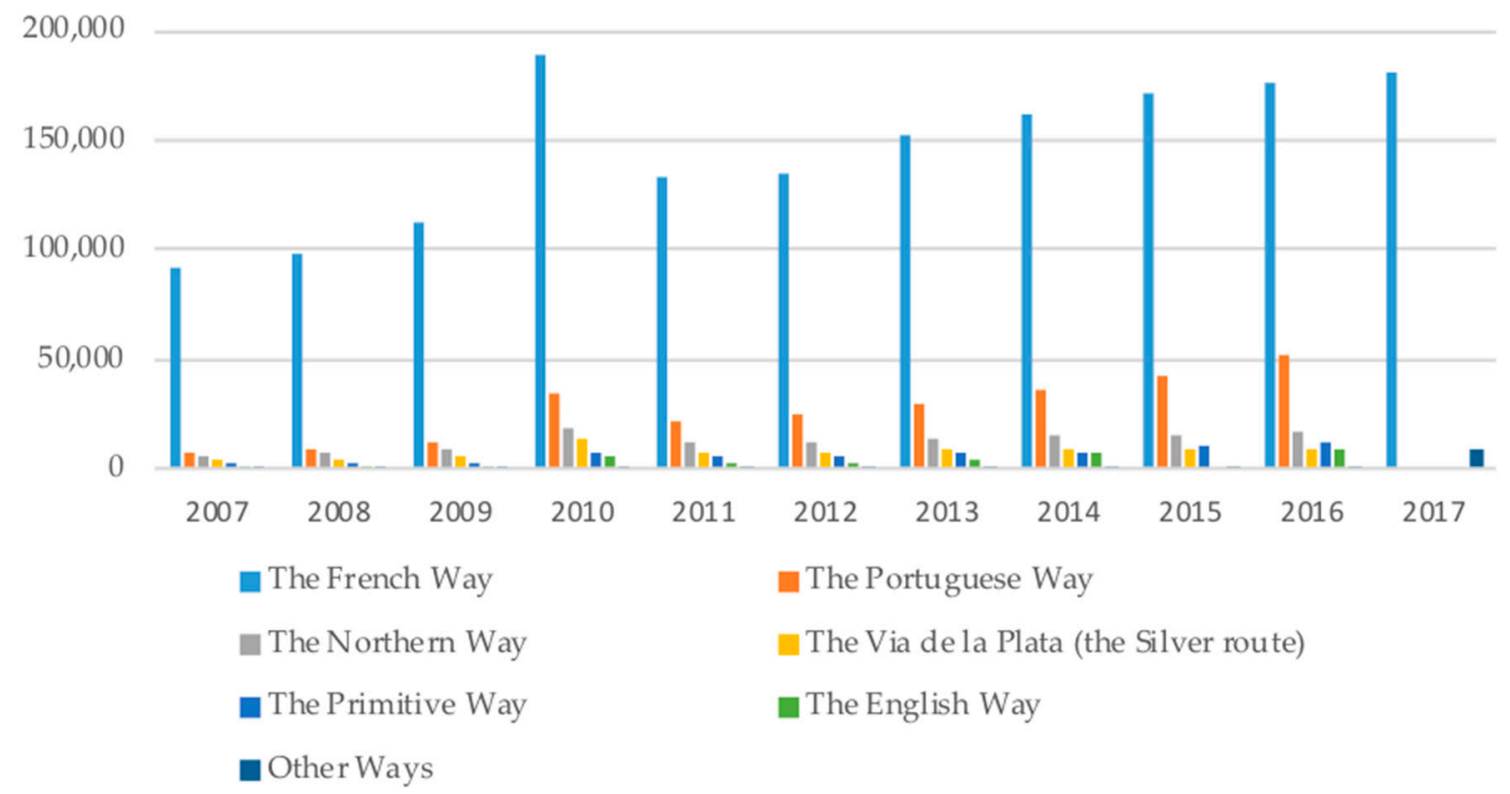

Figure 3. Comparative representation of the chosen St. James itineraries [78].

Firstly, we demonstrate the Way as an opportunity to recover and enjoy means of transport that are respectful of the environment through the expression slow mobility [82]. The means of transport used to travel it are walking, bicycle and horseback (Table 4). Since the Middle Ages, the Spanish verb peregrinar (to make a pilgrimage) meant "to walk", and this is the most authentic way to undertake the Way $[83,84]$. A famous and often repeated phrase by Goethe, "Europe was made on the pilgrim route to Santiago", is a reminder of the reiteration of this practice, which continues today and is consolidated through the increase in the Way's success $[6,83,84]$. Even now, walking is an identity of the Way that is highly regarded, as itis associated with the objective of rest that holidays prioritize [85-88].

Table 4. Means of undertaking the Way [78].

\begin{tabular}{ccccccc}
\hline Year & Walking & Cycling & Horseback Riding & Sailing & Wheelchair & Total Pilgrims \\
\hline 2007 & 94,329 & 19,766 & 364 & 0 & 7 & 114,026 \\
2008 & 104,178 & 21,248 & 293 & 0 & 30 & 125,141 \\
2009 & 121,959 & 25,127 & 342 & 0 & 39 & 145,877 \\
2010 & 237,873 & 33,277 & 1230 & 0 & 37 & 272,135 \\
2011 & 153,078 & 29,948 & 341 & 0 & 11 & 183,366 \\
2012 & 164,749 & 27,406 & 281 & 0 & 22 & 192,488 \\
2013 & 188,187 & 26,649 & 977 & 0 & 66 & 215,880 \\
2014 & 210,939 & 25,325 & 1520 & 0 & 98 & 237,983 \\
2015 & 236,707 & 25,343 & 326 & 0 & 71 & 262,516 \\
2016 & 254,025 & 23,347 & 342 & 15 & 125 & 277,913 \\
2017 & 278,490 & 21,933 & 417 & 153 & 43 & 301,036 \\
\hline
\end{tabular}




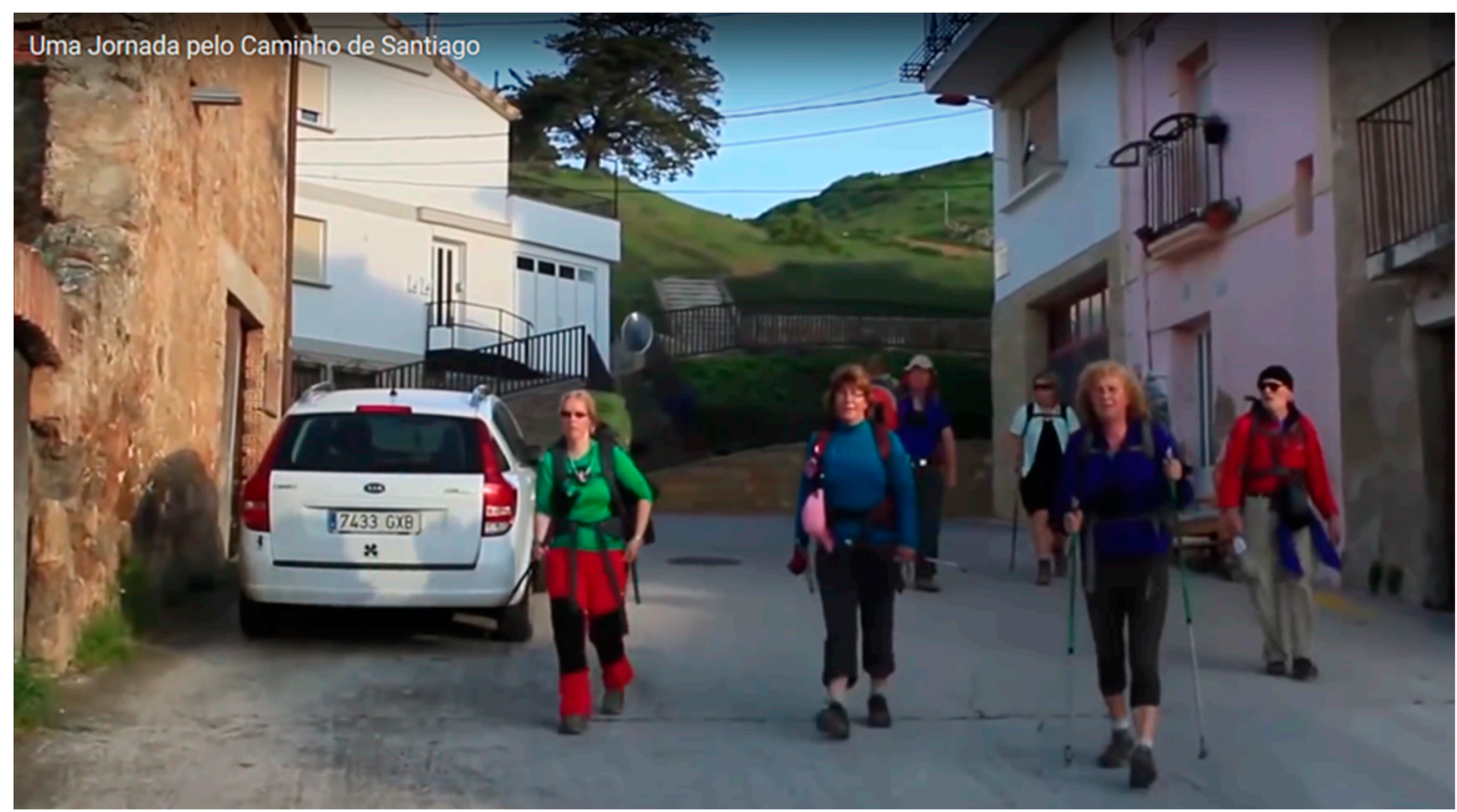

Figure 4. Pilgrims walking [77].

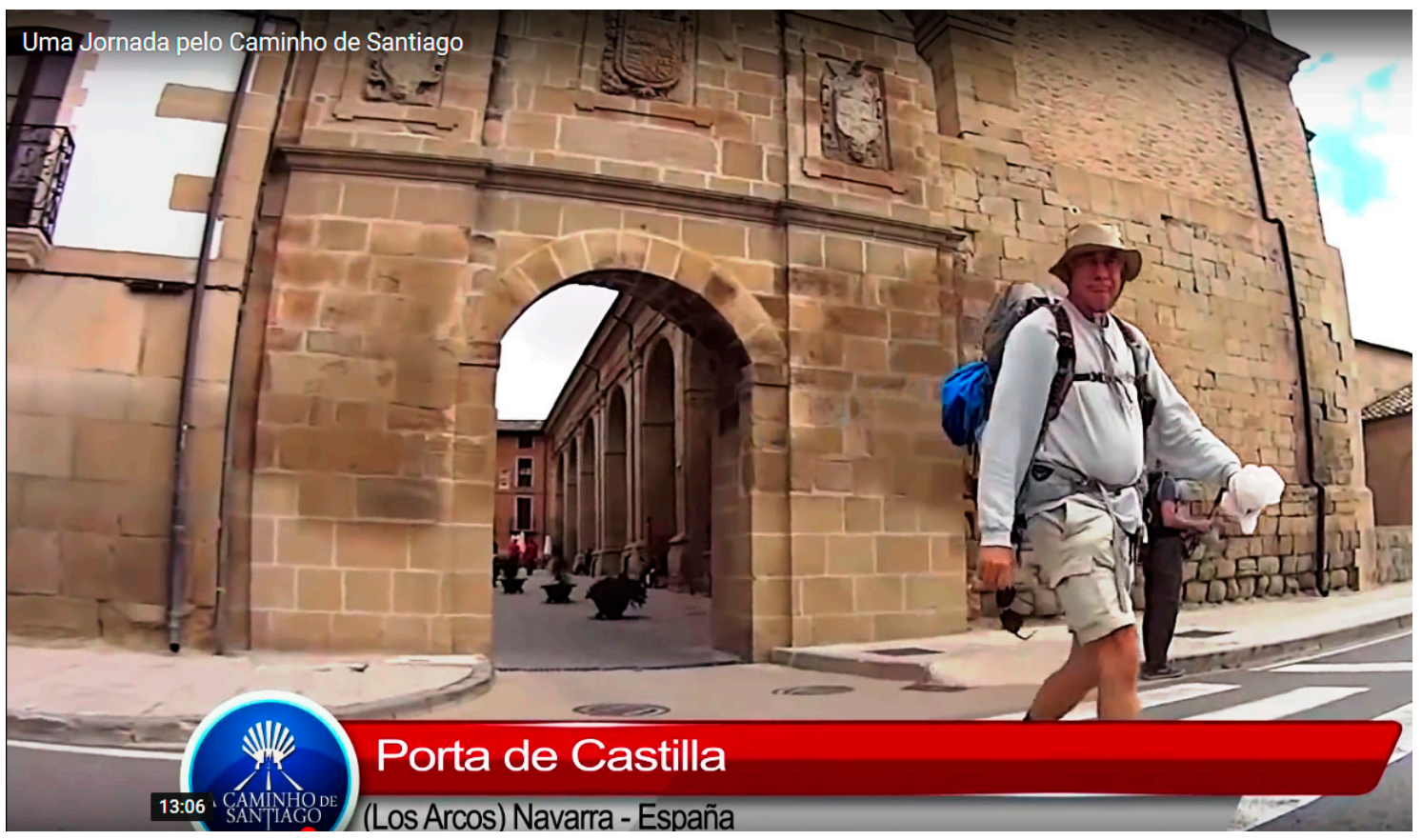

Figure 5. Pilgrim walking and enjoying the cultural heritage [77]. 


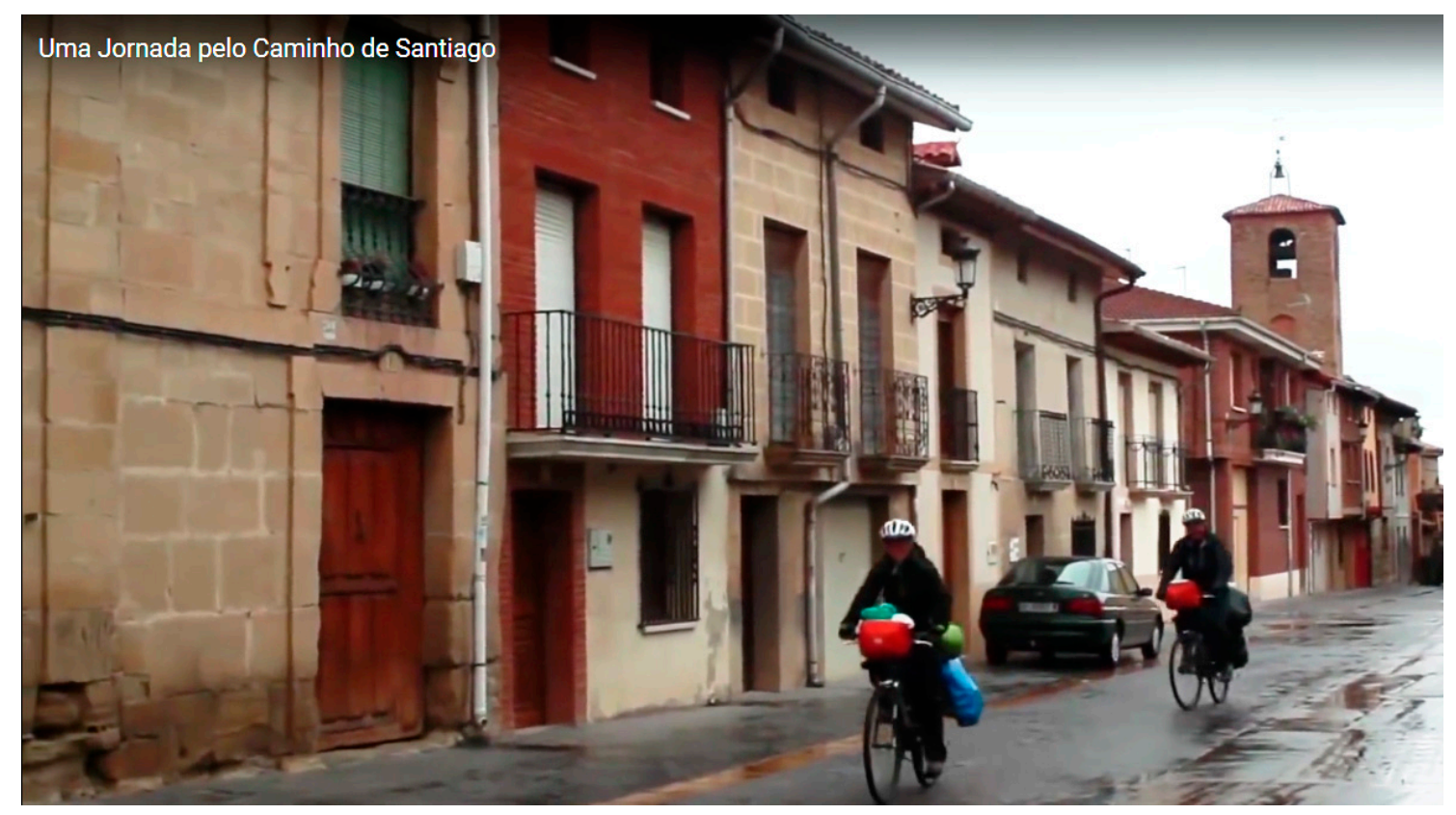

Figure 6. Pilgrims riding in urban centers along the Way [77].

The slow mobility of pilgrimage means assuming a sustainable behavior that is respectful of the environment. Slow mobility is a trait that enables travelers to renew the original relationship between human beings and the environment, to rekindle social relationships, to perform a healthy activity and to enjoy the experience $[84,89]$. The films that represent the Way as such, and pilgrimage in general, contribute to promoting the ideal of slow tourism, in harmony with the environment, and the rural and urban landscapes. Figures 4-6 visualize sustainable tourism based on slow mobility, on foot or on bicycle.

As shown by the data in Table 4, statistics from the Pilgrimage Office confirm that the two most common means of traveling the Way are walking (Figures 4 and 5) and by bicycle (Figure 6). Furthermore, in recent years, the number of pilgrims undertaking the Way by bicycle has increased. This is a post-contemporary reinterpretation of the route that simultaneously consolidates the sustainable practices of the Way. The number of programs and companies that offer assistance to those pilgrims who have to send their bicycles back home once they have reached their goal has grown.

Another sustainable legacy from the past is related to accommodation. Although the profile of the pilgrims is changing because of the increase in pilgrims and the importance of the route, meaning that the number of pilgrims that stay in hotels is growing, the majority continue to choose hostels. They are only allowed to stay for one night at these hostels, except for reasons beyond their control such as illness. According to data provided by the Way of St. James Observatory [89] (latest report of 2010), almost $50 \%$ of pilgrims sleep exclusively in hostels and $75 \%$ use them occasionally. In this case, pilgrims tend not to stay in the same place or the same establishment for longer than one night unless in exceptional circumstances. This causes a high turnover and flow of pilgrims. In addition, pilgrims are not demanding in terms of accommodation and often chose existing religious and/or public structures (Figures 7 and 8). 


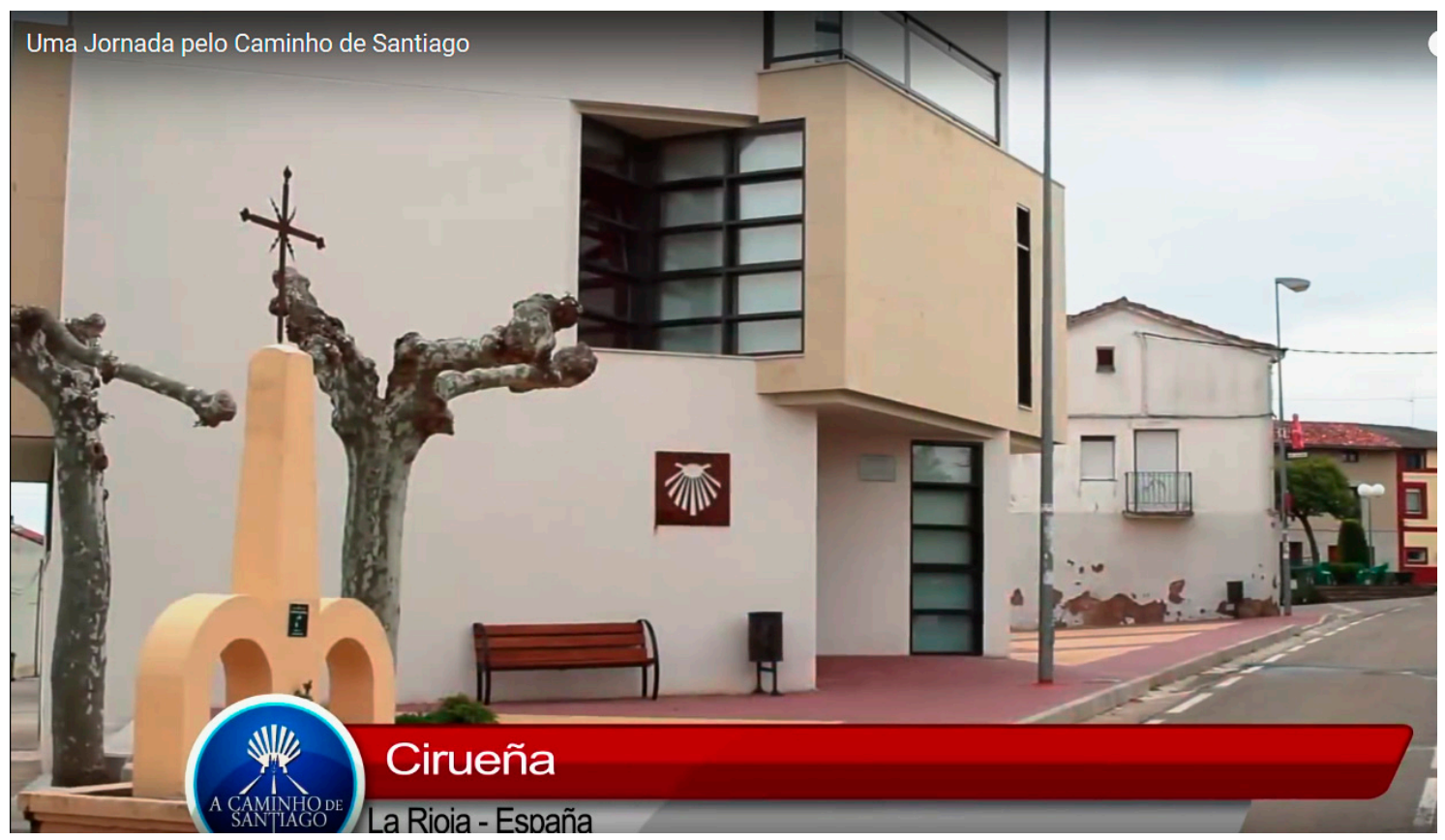

Figure 7. Pilgrims' hostel [77].

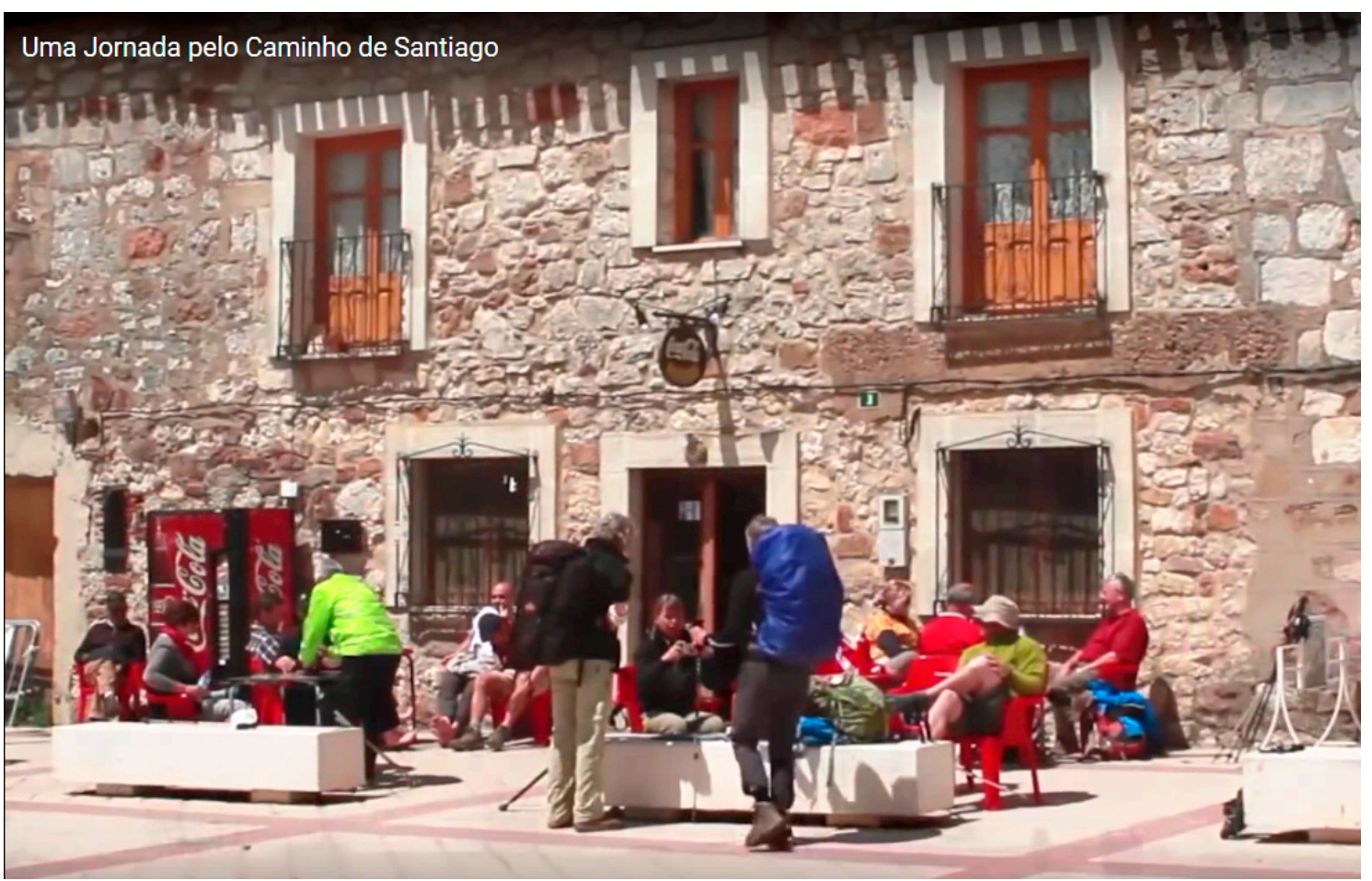

Figure 8. Pilgrims meeting outside hostel [77].

As shown in Figures 7 and 8, the documentaries highlight the most traditional accommodation option, raising awareness amongst viewers, thus promoting the network of hostels.

These cinematographic productions can be considered as strategic in fostering and promoting sustainable tourism in minor centers through pilgrimage. In general, film is a key element in constructing the destination's image [45], since its functions can provide a source of income, help to improve the local economy and generate forms of employment for the community. Film is beneficial for the receiving community, but above all, it impacts the tourism sector, becoming a sources of high added value for the land, since it provides greater visibility and publicity of places, increasing the 
attractiveness of a place, municipality, or region. Notably, pilgrimage no longer has a solely religious purpose, but is nowadays rather secular. This semantic evolution turns the movement of pilgrimage into a type of slow tourism, into a desirable model for the touristic development of the territory, and therefore, of minor cities.

Through the visual cinematographic discourse, we are able to access information pertaining to the heritage offering of the places along the Way (Figures 9-12). In this case, the heritage found along the route is an attraction factor and is well valued by the pilgrims [88-90]. Visiting the heritage offerings of the cities along the pilgrimage route has become a contemporary practice for the Way, as it enriches the experience of and empathy with the territory being explored [91]. The Way is a heritage space, also defined as an open-air museum by B. Castro Fernández [92]. As a consequence, a documentary on the Way must reflect its monumental richness that also expresses its historical roots. This message is conceptualized in the cinematographic images that capture the heritage symbolic elements of the stages traversed. Through these moving images, spectators discover the Way's heritage. According to the interviews completed by the Way of St. James Observatory [89], heritage was one of the reasons for people undertaking the pilgrimage (Figure 13). Despite its temporal distance, in the audiovisual productions, we recognize how heritage continues to be a theoretical image of the Way. Considering that the producer is likely to be interested in the success of their documentary or film, the spectator accesses these urban and heritage locations through captivating images, whose allure is reinforced by the camerawork. In Camino de Santiago. Documentary Film, Mark Shea stops to represent each detail of the Cathedrals of Burgos and León. The same technique is employed in the case of Uma Jornada pelo Caminho de Santiago, in which the Cathedral of Astorga is presented as below.

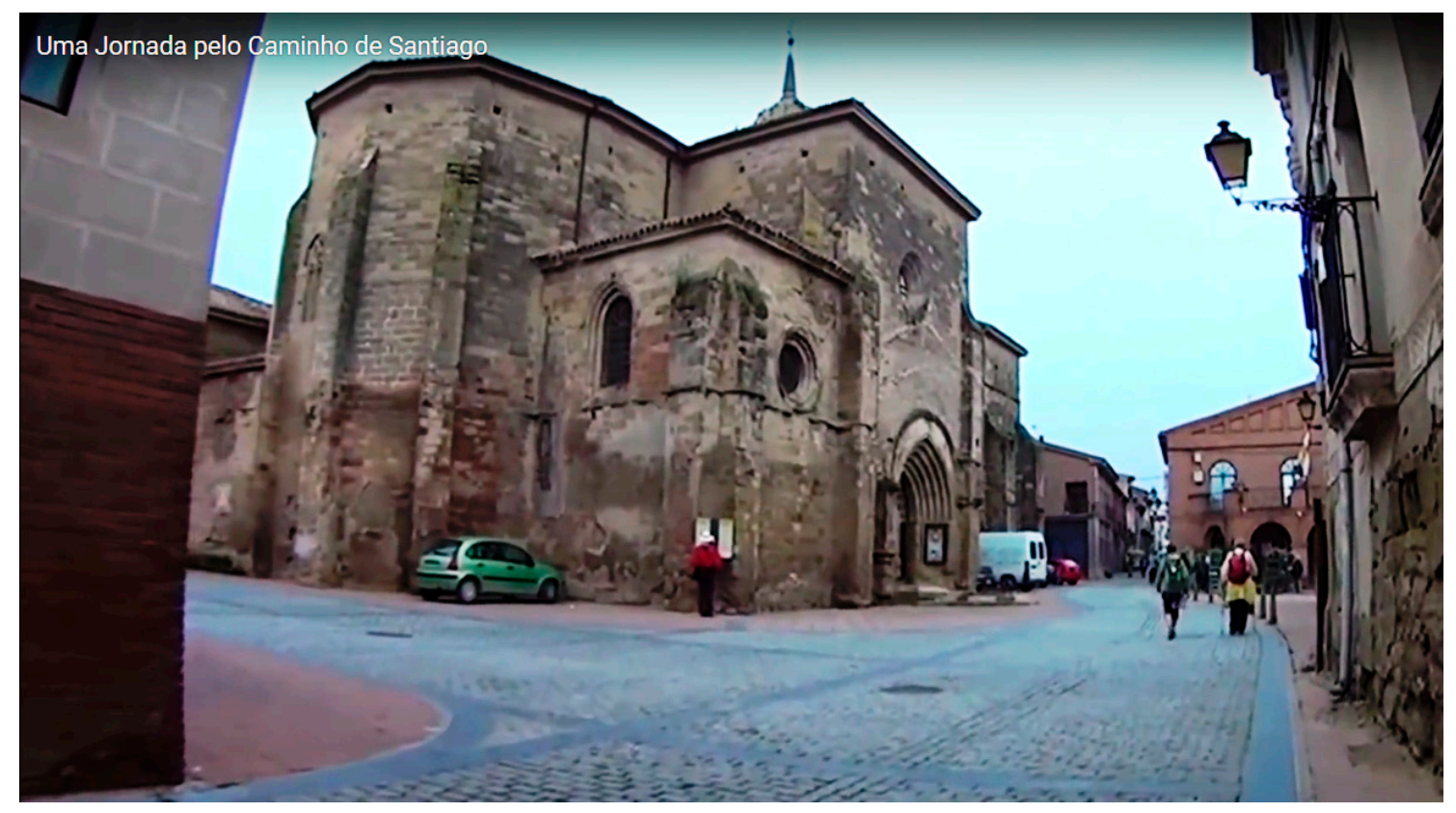

Figure 9. Pilgrims and Urban Heritage [80]. 


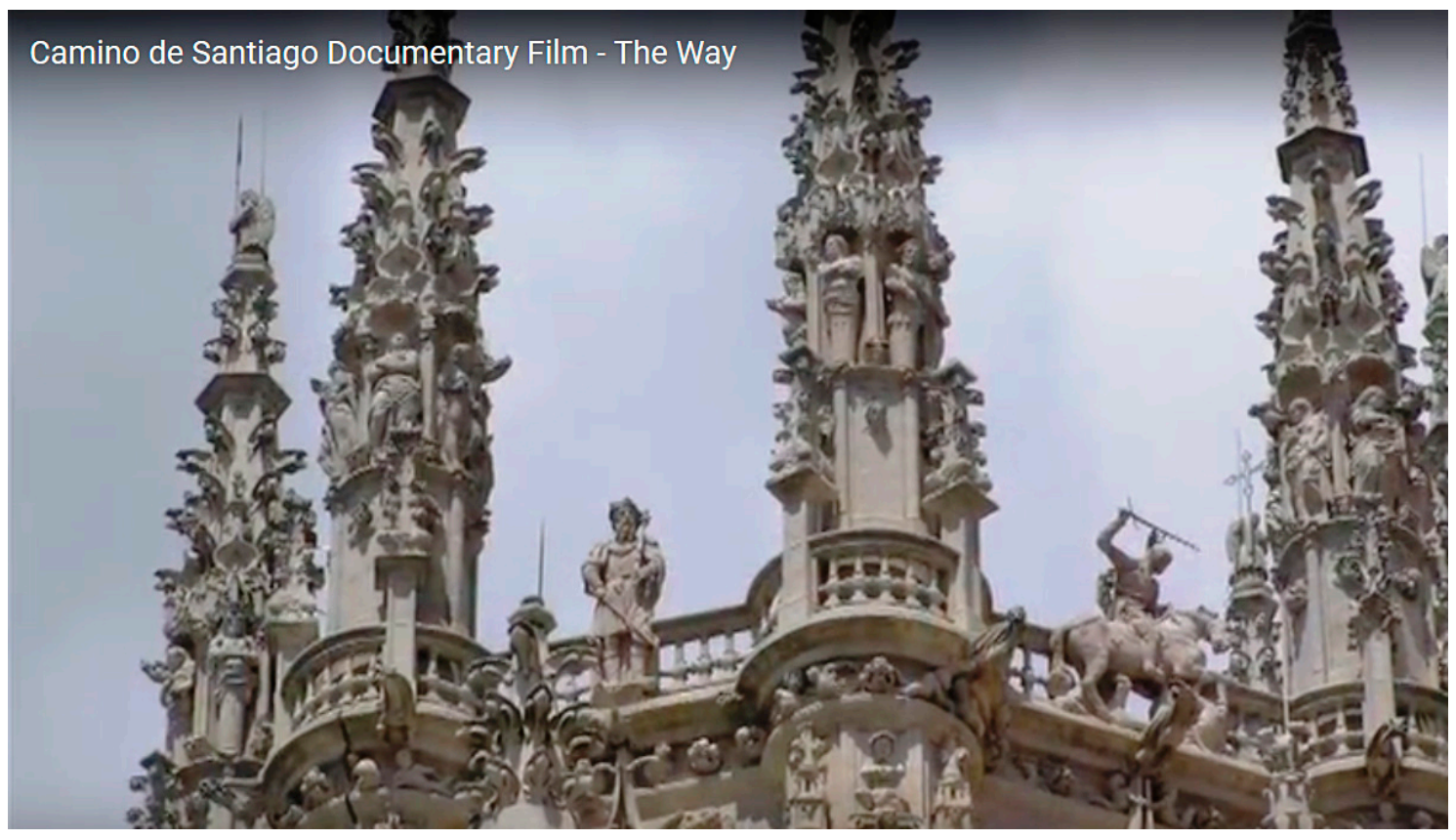

Figure 10. Roof detail of the Cathedral of Burgos [77].

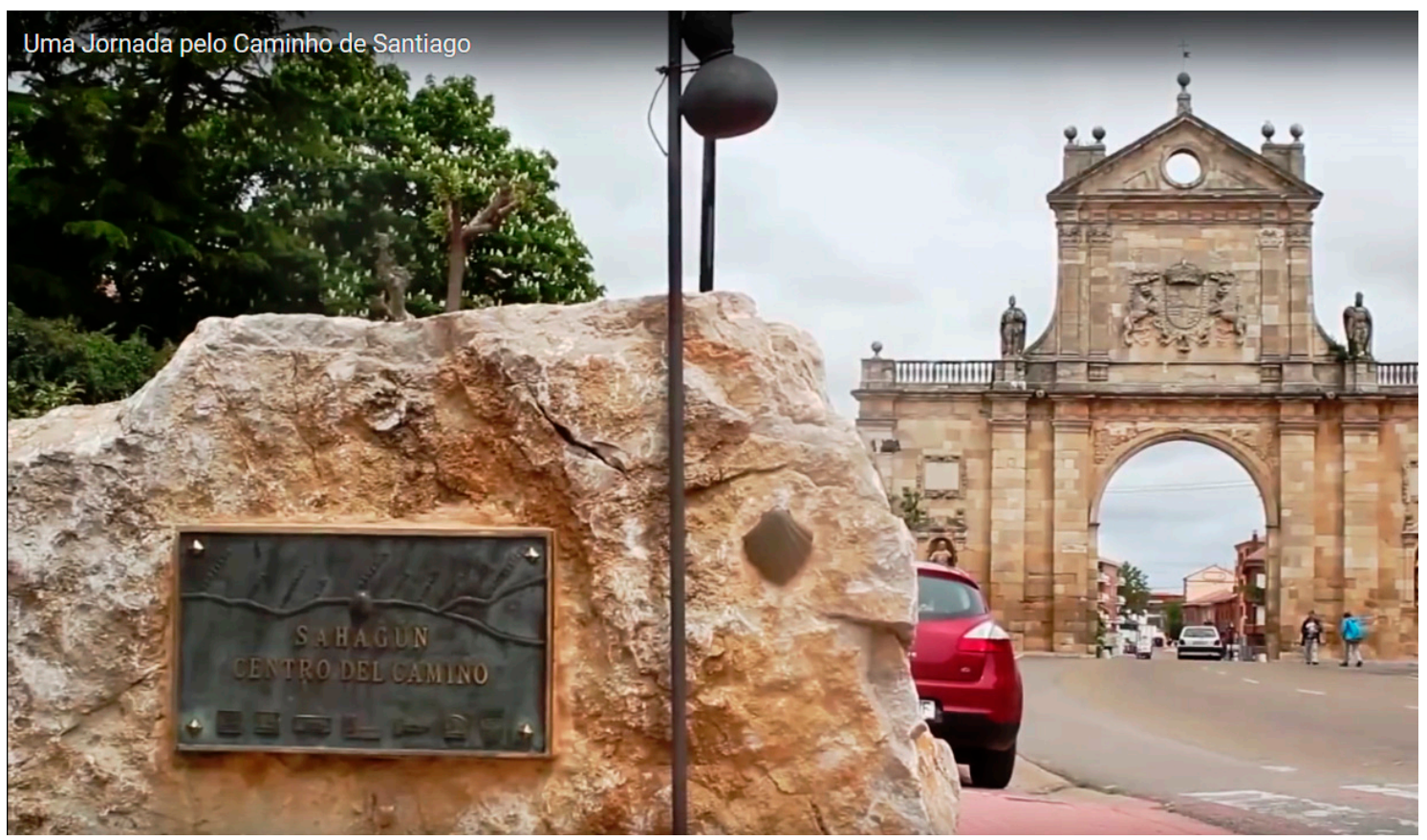

Figure 11. Sahagun. Centro del Camino [77].

Through the following figures, we highlight a key factor in pilgrimage, which is derived from slow mobility: sociability. After a long day walking or pedaling, the rest of the day is spent resting or socializing inside the hostel, which is an essential place for exchanging experiences [87]. From the perspective of sustainability, respect for the environment is also translated into respect for and from the people along the Way. Figures 14 and 15 below depict urban contexts located along the Way and express how the Way's paradigm of sustainability is also applied to the cities traversed. 


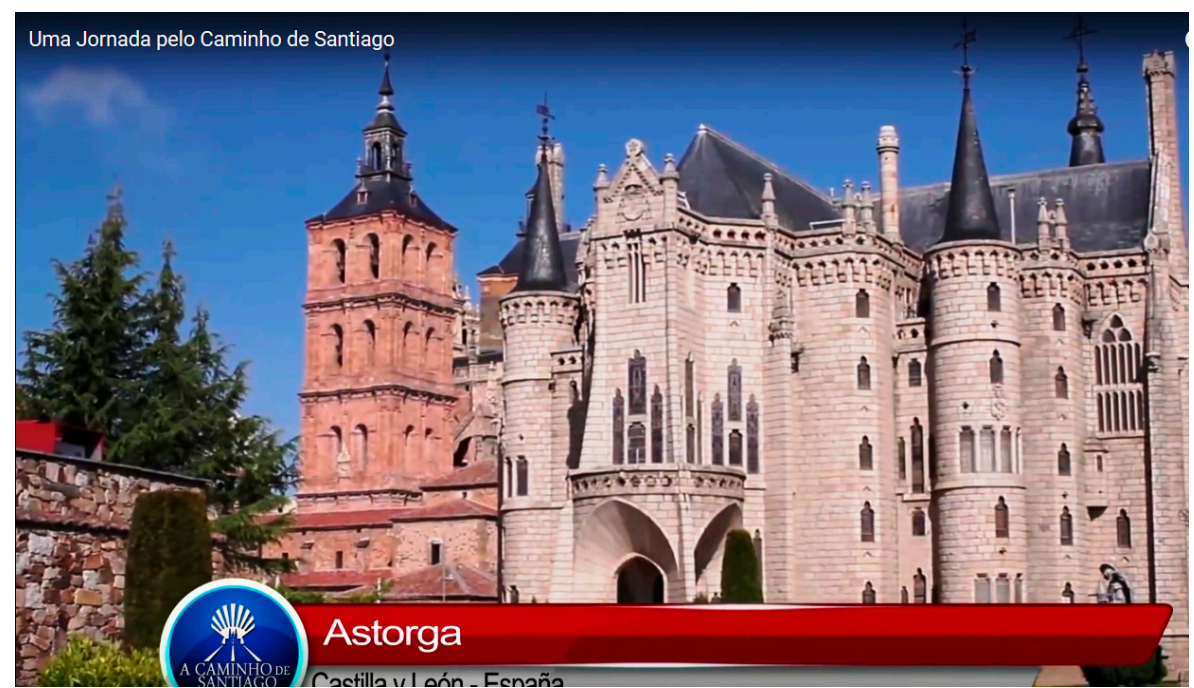

Figure 12. Cathedral of Astorga [77].

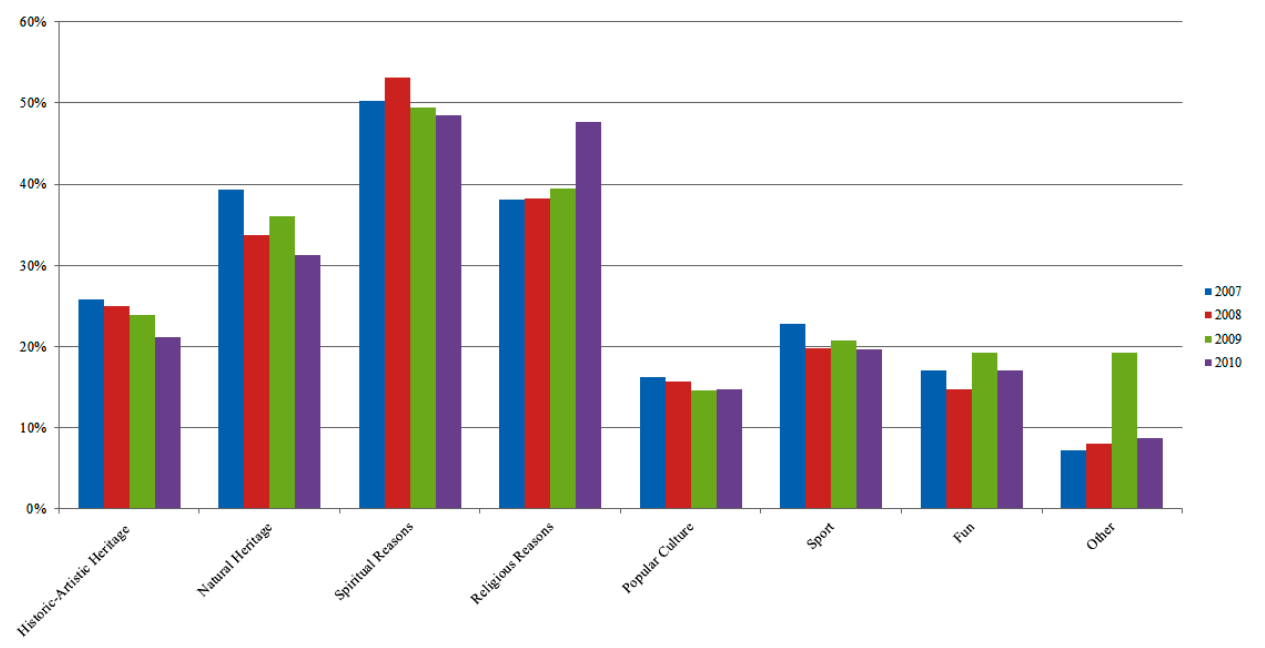

Figure 13. Main reasons to undertake the Way (2007-2010) [89].

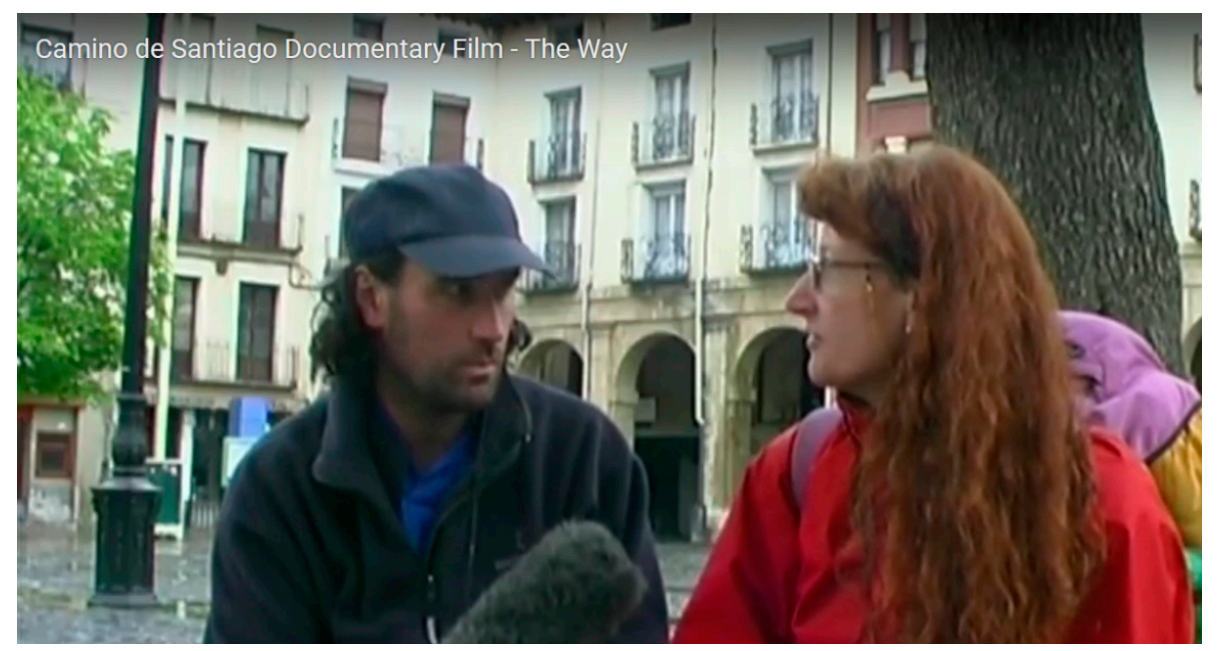

Figure 14. Social moments along the Way [76]. 


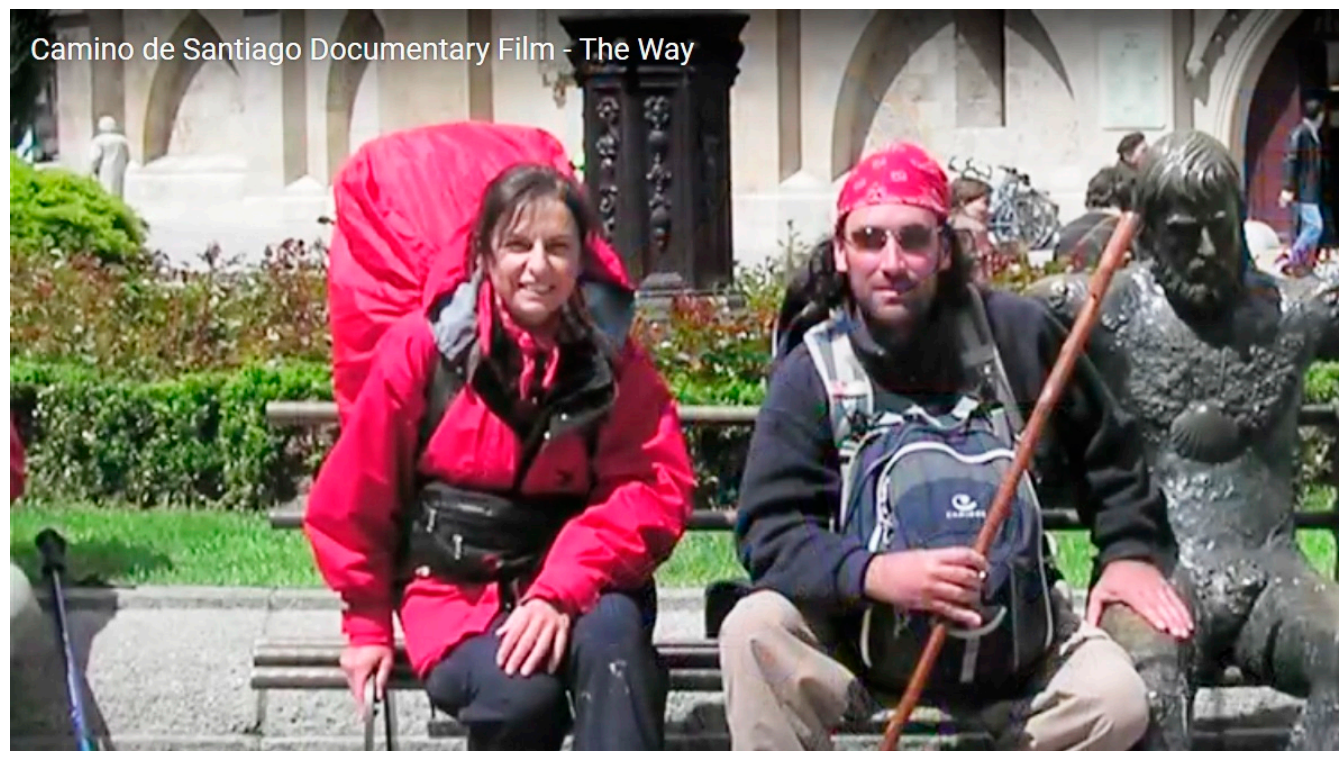

Figure 15. Social moments along the Way [76].

Pilgrimage is an experience that elicits interest because it is another process of understanding humans and their relationship with the land. Furthermore, slow mobility teaches us to understand the land and its resources [91]. The productions analyzed, like many of those linked to the Way, function as a display that allows wine and gastronomy of the region to be promoted (Figure 16). As displayed in the documentaries, pilgrims prefer to consume local products and therefore those based on gastronomic traditions that allow them to harmonize with the surrounding land. The post-contemporary tourist's curiosity and desire to acquire new knowledge also inspires the pilgrim, who fully experiences the Way. One of these experiences is linked to local resources that are used by audiovisual productions. Given that a film needs a location [25,29], an active collaboration between cinema and local resources is necessary $[4,5]$. The cases analyzed are proof of geographical appraisal through cinema, as they visualize the Way's rich offerings: cultural, social, ethnographic and culinary heritage.

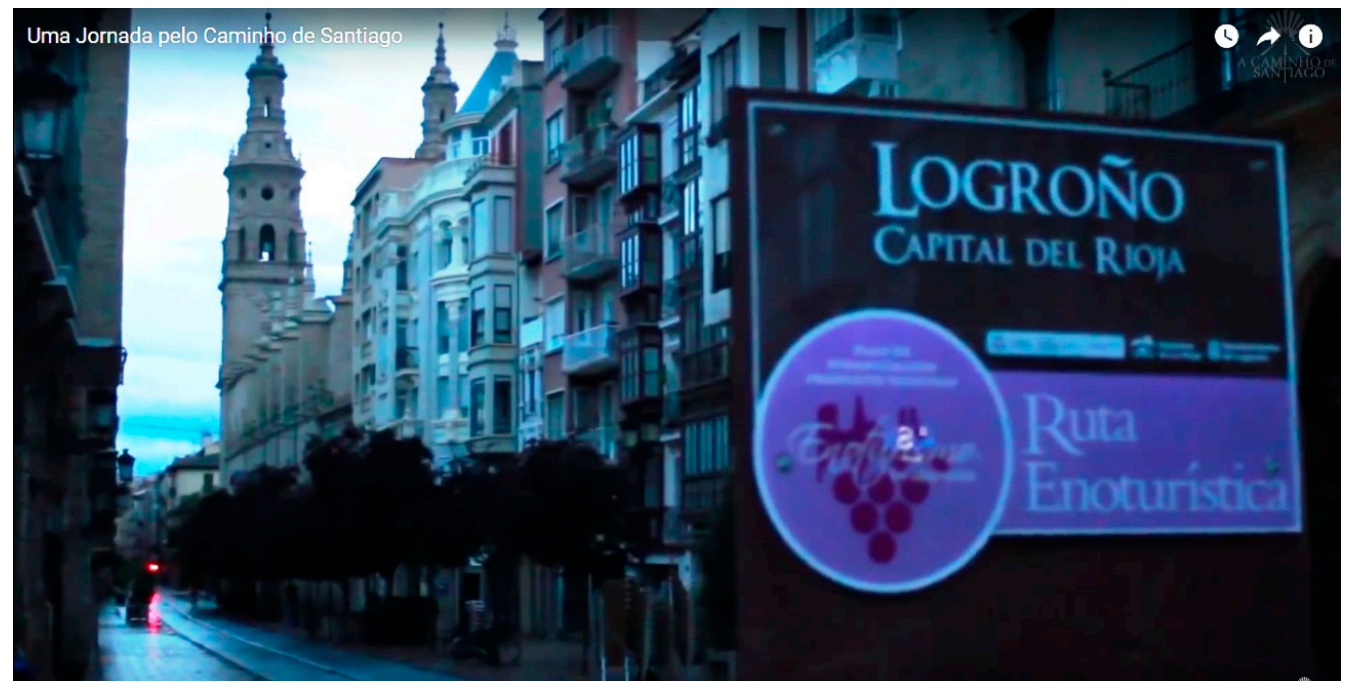

Figure 16. Local resources and cinema production [77].

The results that have been presented coincide with previous studies and with the statistics available relating to the Way of St. James. With these as our basis, we advance a visual theorization of tourist sustainability that emerges from the case studies, which allows for a film-induced sustainable tourism to be talked about, characterized as follows: 
- Slow mobility: inspired by contemporary trends that impose new holiday rhythms and styles [91], the cinema directors and producers exploit the slow mobility of the Way of St. James to films promoting this practice and to teach others how to get closer to the location.

- Film-specific aspects: the cinema productions (especially those available online) are partners in creating successful on-location marketing [37]. The actors' experiences are a sort of visual guide through which the viewer learns about the location, looks ahead to their experience, or can relate to it. Furthermore, cinema tourism can be considered an efficient tool for urban regeneration and economic revitalization.

- Economic benefits: the cinematographic representation not only represents a creative or artistic expression, but also defines a set of complex economic activities based on logic and economic determinants that influence its development and evolution. The local community realizes benefits in the short term, as film improves the destination's image and increases tourist presence, as well as income $[25,30]$. In the mid-to-long term, films boost the area's popularity, and they can reconvert or reinforce the location's image, to improve the infrastructure, optimize the receptive structures, and enhance local artistic and cultural heritage [45]. For the territory and the areas in which it operates, the company that manages the economic activity generated by a cinematographic production represents a direct, indirect, and induced economy, able to generate immediate gains in terms of spending during the processing of the film as well as mediated or induced gains in terms of popularity, positive increase in the image of the destination, occupation, and arrival of flows of tourists and visitors. In the case study, a cinema tourist decides where to stay or stop depending on what they have seen.

- Tourist policies: they should be focused on managing this type of cinema tourism as a competitive geographical strategy $[1,36]$. Some policies could address the need for a load capacity study (possibilities, pros, and cons, etc.), and the promotion of cooperation between public and private actors, so that the enhancement process involves all stakeholders [46]. Also, for the smaller town centers, producing movie maps to complement the itinerary maps) would allow the Way of St. James to be experienced differently, focusing their attention on less congested town centers. We must not forget to consider the tourist sustainability of the destination in relation to protecting and respecting the territory and environment, as well as the place's history, identity, and community. Public and private entities do not yet seem to fully perceive the extent of the problem, since policies are not always outlined to control the effects on the territory resulting from the intensive development of tourism. A real change in course in these new destinations will occur only when these places are considered as real, integrated systems where the interests of public and private actors can converge.

- Sustainability aspects: attention must be paid to the location-community relationship $[4,46]$. The community could feel threatened by the arrival of huge influxes of tourists, and then might not be able to seize all the potential advantages that they would bring to the local economy. In order to avoid these undesirable effects, those responsible for local policies must try to anticipate and assess the consequences that the increase in tourism could involve for the location.

\section{Conclusions}

Tourism is a modern metamorphosis of travel and pilgrimage [86,87]. This secularization has changed its symbolic meaning, transforming places into tourist locations $[80,88,90]$. The growing dimension of contemporary tourism, its characteristics and the transversal dimension of its industry are the main driving forces that have led the search for new tourism approaches. The present work sought to examine the development of a new sustainable tourism approach related to film-making promotion of a well-established global pilgrimage, such as the Way. The film-induced tourism effect plays a pivotal role for a territory. To capture its value and consolidate its effects, tourism offerings must match the expectations created by the filmic narration and appreciate and love the territory's resources and identity, and raise awareness. 
As "film genres are produced by the discourses which describe them" [11] (p. 2), filmic productions representing pilgrimages are engendering a promotional discourse that might slowly turn into a proper genre. Given the original essence of pilgrimage, documentary cinematographic productions coincide in the diffusion of a filmic theorem based on sustainability. As a consequence, this produces practices and regulations for production and configuring the space that are reproduced on an international level. Documentaries about the Way are, therefore, consolidating a framework for signifying space. These documentaries represent the space and they want to create sensations. The moving images amplify these sensory properties as they allow experiences that strengthen the sense of the place to be relived. The representational power of the images is also due to their ability to reproduce the same experience in viewers. It is through this experiential recognition that images have most success. Due to cinema visibility, the Way's town centers, especially those that are smaller in size, could take advantage of the film-induced tourism for their sustainable development (Table 5). Turning these small cities and towns into cinema locations would have an immediate, direct economic impact and an increase in occupancy of hotels. It would increase the professionalism of human resources and tourist consumption, which would require the location to have products, goods, services, professionalism, specialized companies, and facilities. Along the Way of St. James, and throughout the route seen in the films (the French Route), there are already services and facilities linked to tourism (accommodation, restaurants, etc.).

Table 5. Socio-economic impacts of tourist flows in the places of the Way.

\begin{tabular}{cccc}
\hline $\begin{array}{c}\text { Cohesion of Local } \\
\text { Community }\end{array}$ & Economic Benefits & Social Incentives & Social Impacts \\
\hline $\begin{array}{c}\text { Income generation for } \\
\text { civil projects }\end{array}$ & $\begin{array}{c}\text { Increase in seasonal } \\
\text { employment } \\
\text { opportunities }\end{array}$ & $\begin{array}{c}\text { Increased leisure } \\
\text { opportunities }\end{array}$ & Traffic increase \\
\hline $\begin{array}{c}\text { Enhancement of local } \\
\text { image and identity }\end{array}$ & $\begin{array}{c}\text { Development of the } \\
\text { tourism system }\end{array}$ & $\begin{array}{c}\text { Promotion of } \\
\text { organizations in the area }\end{array}$ & Load capacity exceeded \\
\hline $\begin{array}{c}\text { Building the sense of } \\
\text { belonging to the } \\
\text { community }\end{array}$ & $\begin{array}{c}\text { Increase for the induced } \\
\text { tourism }\end{array}$ & $\begin{array}{c}\text { Growth opportunities for } \\
\text { cultural exchange }\end{array}$ & Increased pollution \\
\hline
\end{tabular}

The impacts of film tourism on the community have been the subject of some discussion, primarily by Beeton [25]. Although most impacts are rather similar to tourism in general (increase in revenue, modification of community structure, intra-communal conflicts over tourism development, employment opportunities, improvement of quality of life, conflicts between local community and tourists, cultural exchange, commodification and loss of authenticity and revitalization of local culture), impacts specific to film tourism have yet to be researched in detail, as a review of existing literature suggests little difference between the two. However, how film tourism specifically impacts the local community is arguably the issue of authenticity and representation.

One of the advantages that of the active collaboration between tourism and cinema is the enhancement of the territory through the cinematographic medium, which has the power to enhance the cultural, social and ethnographic heritage more effectively than an image and brand campaign, as a film is, by its very nature, promotion, and communication. A film or series needs a territory for a purely material reason, to provide a context to the narration and for an aesthetic reason to ensure that the territory is coherent with and possibly exalts the screenplay. The cinematographic representation does not represent only a creative or artistic expression, but also defines a set of complex economic activities based on logic and economic determinants, which influence its development and evolution. The company that manages the economic activity generated by a cinematographic product is the production that creates a direct, indirect, and induced economy for the territory and the areas in which it operates, able to generate immediate gains in terms of spending during the processing of the 
film, and mediated or induced gains in terms of popularity, positive image growth of the destination, occupation, and arrival of tourist and visitor flows (Table 5).

A film production requires the use of specialized and heterogeneous goods and services for processing. The production process interacts with the territory on two different levels: one organizational and management, the other purely aesthetic and artistic. The territory is a fundamental resource for production, since it is simultaneously environment, landscape, historical, and artistic heritage, local culture, climate, society and folklore. The aesthetic motivations, such as the uniqueness of the territory as the sum of resources suitable for the subject, the plot, the atmosphere, and the screenplay of the film; and the economic-organizational motivations of project management, such as time, costs, and resources; constitute the decisive mix for choosing one set rather than another. The aesthetic motivations prevail every time the territory necessary to the creation of the artistic product is recognizable in a single location without alternatives. When the film presents various possibilities of setting, the production tries to find the least expensive location in terms of costs, time, and resources. For the territory that is chosen, there are significant opportunities for the economy of the area: direct and immediate economic impact, increase in employment, business specialization, professionalization of human resources, and tourist consumption. The production requires the presence of products, goods, services, professionalism, specialized companies, and structures. The most requested are those that characterize the tourism sector, such as hospitality, transport, and catering. The presence in the same territory of all these resources together, in addition to determining the preference for one location over another, allows the production to work without moving from the locality, saving time and money and with direct, indirect, and induced economic impacts on the host territory. Among these, the occupational repercussions, both during the processing period and permanently, are perhaps the most important, as they allow the specialization of a large number of people and the possibility for local entrepreneurial realities to grow and acquire useful knowledge. What the producers expect from the territory is adequate problem-solving capacity, so those places that guarantee these services are preferred.

Despite the relevance for stakeholders, no research has examined on the theoretical and visual exploration of these sources, which are accessible and are frequently consulted online by potential pilgrims. Likewise, this work advances a new line of research that invites reflection on possible theorizing in the audiovisual industries. The two documentaries highlight how tourist sustainability joins with the simplicity of pilgrimage, in that the pilgrim and/or tourist does not need much to thrive $[84,86,91]$. Bringing the pilgrim figures closer to tourist practices confirms the growing overlap of behaviors and the need to investigate the pilgrimage experience from new perspectives. Regarding advertising and communication tools, cinema has revolutionized perceptions when reproducing geographical spaces and its movements [93]. At present, we limit ourselves to defending theoretical possibilities of the documentaries, which are tools for disseminating a filmic theorem that is amplified when they can be consulted via the internet. It is true that this research has its limitations, as direct contact with producers and participating pilgrims would allow our results to be confirmed, but we think that in this preliminary stage, the scientific backing of the previous investigations is important in order to confirm our hypothesis. The communication potential of cinema highlights geographical resources and, in the case studies, contributes to understanding the films as tools for reflection on the potential for town center destinations. For this reason, as far as future research directions are concerned, destination management organizations must consider the economic advantages of film-induced tourism along with its negative economic, social, and environmental impacts. Networking between stakeholders representing different interests can help with planning and controlling film-induced tourism within a more ethical and sustainable context. Therefore, film-induced tourism must be an instrument capable of activating interventions and generating long-term benefits for the offerings of destinations, with the aim of not only of increasing arrivals in the short-term, but also encouraging trips to be repeated, or tourists to extend their visits (Table 5). The territory's task is to specialize in supplying quality resources, services, and interventions in favor of productions, and have the ability 
to respond to the opportunity that this demand is able to provide. In this sense, if television can attract viewers and make them aware of a place, it can be considered an instrument of indirect promotion, so it is important that the location assigned to tourist destinations is effectively equipped and ready to welcome visitors. Thus, there is a need to reflect more deeply on the local and behavioral impacts of moving images. The new format of territorial promotion that has used cinema and television in recent years can represent, for Santiago de Compostela, an opportunity for the rejuvenation of the target of visitors, tourists, and users and for its tourist image that has been expanded to the domestic and international markets. The potential of the cinematographic medium is manifold. It is a vehicle of attraction for tourists who would not have otherwise visited the place, encourages the return of prior visitors, and generates longer stays and greater expenditures. Moreover, it is a tool that is able to expand the target market of a destination and to implement place marketing actions. Interpreting tourism in this new light allows operators in the sector to use the film product further to trigger a process of socio-economic growth, especially in those local areas that need to create opportunities for younger generations.

Author Contributions: Three authors contributed to this research and jointly work on the publication providing literature review and writing it. L.L. wrote and reviewed the sections: "3. Materials and Methods" and " 4 . Results \& Discussion". E.N. wrote and reviewed the section: "2. Literature Review" and "5. Conclusions". R.C.L.G. wrote and reviewed the sections: "1. Introduction".

Funding: This research received no external funding.

Conflicts of Interest: The authors declare no conflict of interest.

\section{References}

1. Lizotte, M.; Grenier, A.A. Ciné-tourisme: Le nouvel eldorado des destinations touristiques. Téoros 2011, 30, 73-78. [CrossRef]

2. Lois González, R.C. Dotaciones y infraestructuras del Camino de Santiago. Una aproximación geográfica. In Ciudades y Villas Camineras Jacobeas: III Jornadas de Estudio y Debate Urbanos; En López Trigal, L., Ed.; Universidad de León, Secretariado de Publicaciones: León, Spain, 2000; pp. 225-245. ISBN 9788477198673.

3. Solla, S.; Xosé, M. Mitos y realidades del Xacobeo. Bol. AGE 1999, 28, 103-117.

4. Saarinen, J. Critical Sustainability: Setting the Limits to Growth and Responsibility in Tourism. Sustainability 2014, 6, 1-17. [CrossRef]

5. Goodwin, H. Contemporary policy debates: Reflections on 10 years of pro-poor tourism. J. Policy Res. Tour. Leis. Events 2009, 1, 90-94. [CrossRef]

6. Lois González, R. The Camino de Santiago and its contemporary renewal: Pilgrims, tourists and territorial identities. Cult. Relig. 2013, 14, 8-22. [CrossRef]

7. Lopez, L.; Santomil Mosquera, D.; Lois González, R. Film-Induced Tourism in The Way of Saint James. Almatour. J. Tour. Cult. Territ. Dev. 2015, 6, 18-34. [CrossRef]

8. Rodríguez Campo, M.L.; Fraiz Brea, J.A. Consideraciones estratégicas para la promoción del Turismo en Galicia través del cine. Revista Galega de Economía 2010, 19, 1-11.

9. Escudero Gomez, L.A. La Imagen Urbana De Santiago De Compostela (España), Un Estudio De Su Representación Pública, Mediática, Promocional Y Artística. Bol. Asoc. Geógr. Esp. 2013, 62, 265-294. [CrossRef]

10. Smith, A.T. Time Warp: Cinematic Pilgrimage to Lourdes and Santiago. Int. J. Relig. Tour. Pilgr. 2017, 5, 55-62. [CrossRef]

11. Hurault-Paupe, A. The paradoxes of cinematic movement: Is the road movie a static genre? Miranda 2014, 10. [CrossRef]

12. Tomlinson, J. Globalization and Culture; Chicago University Press: Chicago, IL, USA, 1999; pp. 1-248. ISBN 9780226807683.

13. Hall, S. Culture nuove in cambio di culture vecchie. In Luoghi, Culture e Globalizzazione; Massey, D., Jess, P., Eds.; UTET Libreria: Torino, Italy, 2001; ISBN 9788877506733.

14. Riley, R.; Baker, D.; van Doren, C.S. Movie Induced Tourism. Ann. Tour. Res. 1998, 25, 919-935. [CrossRef] 
15. Tooke, N.; Baker, M. Seeing is believing: The effect of film on visitor numbers to screened locations. Tour. Manag. 1996, 17, 87-94. [CrossRef]

16. Iwashita, C. Media representation of the UK as a destination for Japanese tourists: Popular culture and tourism. Tour. Stud. 2006, 6, 59-77. [CrossRef]

17. Fantuzzi, N.; Gazerro, M. Cinema e Geografia: La crisi del paesaggio italiano. Il Tetto 1999, 219, 85-96.

18. Escher, A. The Geography of Cinema. A cinematic World. Erdkunde 2006, 60, 307-314. [CrossRef]

19. Koebner, T. Insel und Dschungel-Zwei Landschaftstypen im Film. Ein Exkurs. In Natur und Ihre Filmische Auflösung; Berg, J., Hoffmann, K., Eds.; Timbuktu-Verlag: Marburg, Germany, 1994; pp. 95-108. ISBN 3-930934-00-0.

20. Escher, A.; Zimmermann, S. Geography meets Hollywood. Die Rolle der Landschaft im Spielfilm. Geogr. Z. 2001, 89, 227-236.

21. Higson, A. The landscape of television. Landsc. Res. 1987, 12, 8-13. [CrossRef]

22. Benjamin, W. Paris, Capital of the Nineteenth Century. Dissent 1970, 77-88. Available online: http:/ / www. no-w-here.org.uk/paris\%20capital.pdf (accessed on 20 February 2018).

23. Vagionis, N.; Lumioti, M. Movies as a tool of modern tourist marketing. Tour. Int. Multidiscip. J. Tour. 2011, 6, 353-362.

24. Roesch, S. The Experiences of Film Locations Tourists; Channel View Publications: Bristol, Germany, 2009; pp. 1-272. ISBN 9781845411206.

25. Beeton, S. Film-Induced Tourism; Channel View Publications: Clevedon, UK, 2005; pp. 1-248. ISBN 9780226807683.

26. Cohen, J. Promotion on Overseas Tourism through Media Fiction. In Tourism Services and Marketing: Advances in Theory and Practice; Bendy, J.W., Ed.; TTRA: Cleveland, OH, USA, 1986; pp. 229-237.

27. Butler, R.W. The Influence of the Media in Shaping International Tourist Patterns. Tour. Recreat. Res. 1990, 15, 46-53. [CrossRef]

28. Beeton, S. Understanding Film-Induced Tourism. Tour. Anal. 2006, 11, 181-188. [CrossRef]

29. Macionis, N. Understanding the Film-Induced Tourist. In Proceedings of the International Tourism and Media Conference; Frost, W., Croy, W.C., Beeton, S., Eds.; Tourism Research Unit, Monash University: Melbourne, Australia, 2004; pp. 86-97.

30. Beeton, S. Smiling for the camera: The influence of film audiences on a budget tourism destination. Tour. Cult. Commun. 2001, 3, 15-26. [CrossRef]

31. Karpovich, A.I. Theoretical Approaches to Film-Motivated Tourism. Tour. Hosp. Plan. Dev. 2010, 7, 7-20. [CrossRef]

32. Torchin, L. Location, Location, Location: The Destination of the Manhattan TV Tour. Tour. Stud. 2002, 2, 247-266. [CrossRef]

33. Heitmann, S. Film Tourism Planning and Development: Questioning the Role of Stakeholders and Sustainability. Tour. Hosp. Plan. Dev. 2010, 7, 31-46. [CrossRef]

34. Busby, G.; Klug, J. Movie Induced Tourism: The Challenge of Measurement and Other Issues. J. Vacat. Mark. 2001, 7, 316-332. [CrossRef]

35. Connell, J. Toddlers, Tourism and Tobermory: Destination marketing issues and TV induced tourism. Tour. Manag. 2005, 26, 763-776. [CrossRef]

36. Croy, W.G. Planning for Film Tourism: Active Destination Image Management. Tour. Hosp. Plan. Dev. 2010, 7, 21-30. [CrossRef]

37. O'Connor, N.; Flanagan, S.; Gilbert, D. The integration of film-induced tourism and destination branding in Yorkshire, UK. Int. J. Tour. Res. 2008, 10, 423-437. [CrossRef]

38. Soliman, M.D. Exploring the role of film in promoting domestic tourism: A case study of Al Fayoum, Egypt. J. Vacat. Mark. 2011, 17, 225-235. [CrossRef]

39. Benzine, A. Lost Drives Sales for Lush Hawaii. Int. J. Tour. Res. 2005, 14, 25.

40. Beeton, S. Location, Location, Location: Film Corporations Social Responsibilities. J. Travel Tour. Mark. 2008, 24, 107-114. [CrossRef]

41. Belch, G.; Belch, M. Advertising and Promotion: An Integrated Marketing Communications Perspective; McGraw-Hill: New York, NY, USA, 2004; pp. 1-880. ISBN 9780078028977.

42. Shani, A.; Wang, Y.; Hudson, S.; Gil, S.M. Impacts of a historical film on a destination image of South America. J. Vacat. Mark. 2009, 15, 229-242. [CrossRef] 
43. Riley, R.; van Doren, C.S. Movies as Tourism Promotion: A Pull Factor in a Push Location. Tour. Manag. 1992, 13, 267-274. [CrossRef]

44. Urry, J. The Tourist Gaze; Sage: London, UK, 1990; pp. 1-192. ISBN 978-0803981829.

45. Nicosia, E. Il Film Induced Tourism leva di sviluppo territoriale? Il ruolo della "filmogenia" marchigiana nel cinema italiano. Bollettino della Società Geografica Italiana 2015, VIII, 555-575. Available online: http://societageografica.net/wp/wp-content/uploads/2016/08/nicosia_ita.pdf (accessed on 20 February 2018).

46. Nicosia, E. Cineturismo e Territorio. Unpercorso Attraverso i Luoghi Cinematografici; Pàtron Editore: Bologna, Italy, 2012; pp. 1-228. ISBN 9788855531436.

47. Scottish Tourism Board. Film Tourism Guidelines for the Tourism Industry; Scottish Tourism Board: Edinburg, UK, 1997; Available online: http:/ / www.visitscotland.org/research_and_statistics/tourism_sectors/film_ tourism.aspx (accessed on 20 February 2018).

48. Buchmann, A.; Moore, K.; Fisher, D. Experiencing film tourism: Authenticity fellowship. Ann. Tour. Res. 2010, 37, 229-248. [CrossRef]

49. Hudson, S.; Ritchie, B.J.R. Promoting destinations via film tourism: An empirical identification of supporting marketing initiatives. J. Travel Res. 2006, 44, 387-396. [CrossRef]

50. Hogg, R. Join the set-jet and see the reel world. Yorkshire Post, 9 August 2005.

51. Di Cesare, F.; Rech, G. Le Produzioni Cinematografiche, Il Turismo, Il Territorio; Carocci: Roma, Italy, 2007; ISBN 9788843043217.

52. Kim, H.; Richardson, S.L. Motion Picture Impacts on Destination Images. Ann. Tour. Res. 2003, 30, $216-237$. [CrossRef]

53. Lefebvre, H. The Production of Space; Blackwell: Oxford, UK, 1991; pp. 1-464. ISBN 978-0631181774.

54. Piazza, R.; Bednarek, M.; Rossi, F. Telecinematic Discourse: Approaches to the Language of Films and Television Series; John Benjamins Publishing Company: Amsterdam, The Netherlands; Philadelphia, PA, USA, 2001; pp. 1-315. ISBN 9789027256157.

55. Chepinchikj, N.; Thompson, C. Analysing cinematic discourse using conversation analysis. Discourse Context Media 2016, 14, 40-53. [CrossRef]

56. Dynel, M. "You talking to me?" The viewer as a ratified listener to film discourse. J. Pragmat. 2011, 43, 1628-1644. [CrossRef]

57. Rose, G. Visual Methodologies: An Introduction to the Interpretation of Visual Materials; SAGE Publications: London, UK; Thousand Oaks, CA, USA; New Delhi, India, 2009; pp. 1-240. ISBN 0761966641.

58. Stafford, B.M. Body Criticism: Imaging the Unseen in Enlightenment Art and Science; MIT Press: London, UK, 1991; pp. 1-612. ISBN 978-0262691659.

59. Jenks, C. The centrality of the eye in Western culture. In Visual Culture; Jenks, C., Ed.; Routledge: London, UK, 1995; pp. 1-12. ISBN 978-0415106238.

60. Peri-Bader, A. Everyday experience in Israeli cinema: The port and the city's margin. Emot. Spain Soc. 2016, 18, 17-26. [CrossRef]

61. Damisch, H. L'Origine de la Perspective; Flammarion: París, France, 1987; pp. 1-478. ISBN 9782081282582.

62. Vancheri, L. Film, Forme, Théorie; Editions Le Harmattan: París, France, 2002; pp. 1-56. ISBN 2-7475-2909-6.

63. Didi-Huberman, G. Phamses, Essais sur L'apparition; Minuit: París, France, 1998; pp. 1-256. ISBN 9782707316288.

64. Mciver Lopes, D. Comprendre les Images. Une Théorie de la Représentation Iconique; Translation and Presentation by Laure Blanc-Benon; Presses Universitarires de Rennes: Rennes, France, 2014; pp. 1-298. ISBN 978-2-7535-3415-5.

65. Goliot-Lété, A. L'image de Film Inventé para L'Analyse. In L'analyse du Film en Question: Regards, Champs, Lectures; En Nacache, J., Ed.; Le Harmattan: Paris, France, 2006; ISBN 978-2-296-00815-1.

66. Esquenazi, J.P. L'analyse de Film Avec Deleuze; CNRS Editions: Paris, France, 2017; pp. 1-208. ISBN 978-2-271-09511-4.

67. Hervé, J.-L. L'analyse de film entre exemple et exception: Préalables a une ontologie. In L'analyse du Film en Question: Regards, Champs, Lectures; En Nacache, J., Ed.; Le Harmattan: Paris, France, 2006; pp. 51-67. ISBN 978-2-296-00815-1.

68. Joly, M. Introduction à L'analyse de L'image, 3rd ed.; Armad Colin: París, France, 2015; pp. 1-160. ISBN 978-2200293628. 
69. Deleuze, G. L'Image-Temps; Cinéma 2. Collection Critique; Les Éditions De Minuit: París, France, 1985; pp. 1-384. ISBN 978270731047.

70. Ferro, M. Cinéma et Histoire; Denoel-Gonthier: Paris, France, 1977; pp. 1-290. ISBN 978-2070328055.

71. Barthes, R. Rhétorique de l'image. Communications 1964, 4, 40-51. [CrossRef]

72. Gombrich, E.H. L'art et L'illusion, Psychologie de la Représentation Picturale; Gallimard: Paris, France, 1971; pp. 1-560. ISBN 978207070988.

73. Frèmont, A. La Région, Espace Vécu; Flammarion: Paris, France, 1999; pp. 1-288. ISBN 9782080814296.

74. Bories, C.; Chagnard, P. Le réel existe, c'est le film. Réflexions sur le cinéma documentaire. Chimères 2017, 2, 27-29. [CrossRef]

75. Connell, J. Film tourism e Evolution, progress and prospects. Tour. Manag. 2012, 33, 1007-1029. [CrossRef]

76. Camino de Santiago Pilgrimage the Way Film. 2010. Available online: http:/ / www.overlander.tv/the-waycamino-de-santiago-film/ (accessed on 20 February 2018).

77. Uma Jornada Pelo Caminho de Santiago. 2014. Available online: https://www.youtube.com/watch?v= DLsPX2K9vv0movie=tt2406422 (accessed on 20 February 2018).

78. Oficina del Peregrino. Santiago Pilgrim Office. Available online: www.archicompostela.org (accessed on 20 August 2018).

79. Davie, G. Religion in Modern Europe. A Memory Mutates; Oxford University Press: Oxford, UK, 2000; pp. 1-23. ISBN 9780198280651.

80. Gil de Arriba, C. Turismo religioso y el valor sagrado de los lugares: Simbología identitaria y patrimonialzación del Monasterio de Santo Toribio de Liébana (Cantabria). Cuadernos de Turismo 2006, 18, 77-102.

81. Rinschede, G. Forms of Religious Tourism. Ann. Tour. Res. 1992, 19, 51-67. [CrossRef]

82. Urry, J. Mobilities; Polity: Cambridge, UK, 2007; pp. 1-336. ISBN 978-0-745-63419-7.

83. Lois González, R.C.; Lopez, L. El Camino de Santiago: Una aproximación a su carácter polisémico desde la geografía cultural y el turismo. Documents d'Anàlisi Geogràfica 2012, 58, 459-479. [CrossRef]

84. Santos, X.M.; Lois, R. El Camino de Santiago en el contexto de los nuevos turismos. Estudios Turísticos 2011, 189, 95-116.

85. Coleman, S.; Eade, J. Reframing Pilgrimage. Cultures in Motion; Routledge: London, UK, 2004; pp. 1-224. ISBN 978-0415303552.

86. Frey, L.N. Pilgrim Stories: On and Off the Road to Santiago; University of California Press: Berkeley, CA, USA; London, UK, 1998; pp. 1-298. ISBN 978-0520217515.

87. Ivakhiv, A. Nature and Self in New Age Pilgrimage. Cult. Relig. 2003, 4, 93-118. [CrossRef]

88. Lopez, L.; Lois González, R.C.; Castro Fernández, B.M. Spiritual Tourism on the Way of Saint James. The Current Situation. Tour. Manag. Perspect. 2017, 24, 225-234. [CrossRef]

89. Cetur, Centro de Estudios Turísticos \& Xacobeo. Observatorio Estatístico do Camiño de Santiago 2007, 2008,2009 e 2010; Universidade de Santiago de Compostela, Xunta de Galicia \& Centro de Estudos Turísticos: Santiago de Compostela, Spain, 2010.

90. Lois González, R.; Castro Fernández, B.; Lopez, L. From Sacred Place to Monumental Space: The Mobility along the Way to St. James. Mobilities 2015, 11, 770-788. [CrossRef]

91. Lois, R.; Santos, X. New trends in urban and cultural tourism: The model of Santiago de Compostela. In New Tourism in the 21st Century: Culture, the City, Nature and Spirituality; Lois, R., Santos, X., Taboada, P., Eds.; Cambridge Scholar Pub.: Cambridge, UK, 2014; pp. 209-234. ISBN 978-1-4438-5892-2.

92. Castro Fernández, B.M. El Redescubrimiento del Camino de Santiago por Francisco Pons-Sorolla; Xunta de Galicia, S.A., Ed.; de Xestión do Plan Xacobeo: Santiago de Compostela, Spain, 2010.

93. Corsi, L. Le cinéma fait sa Havane. Étude des représentations spatiales diffusées par le cinéma des rues cubain et des leurs conséquences sociales. Ann. Géogr. 2014, 1, 822-843. [CrossRef]

(C) 2018 by the authors. Licensee MDPI, Basel, Switzerland. This article is an open access article distributed under the terms and conditions of the Creative Commons Attribution (CC BY) license (http://creativecommons.org/licenses/by/4.0/). 